Prepared in cooperation with the the U.S. Environmental Protection Agency and the Kickapoo Tribe of Oklahoma

A Reconnaissance of Selected Organic Compounds in Streams in Tribal Lands in Central Oklahoma, JanuaryFebruary 2009



Scientific Investigations Report 2010-5110

Revised August 2010 
Cover: The photograph on the cover is a picture of the North Canadian River near Calumet, taken on December 12, 2009, by Joy Savoia, U.S. Geological Survey staff. 


\title{
A Reconnaissance of Selected Organic Compounds in Streams in Tribal Lands in Central Oklahoma, January-February 2009
}

\author{
By Carol J. Becker
}

Prepared in cooperation with the U.S. Environmental Protection Agency and the Kickapoo Tribe of Oklahoma

Scientific Investigations Report 2010-5110

Revised August 2010

U.S. Department of the Interior

U.S. Geological Survey 


\section{U.S. Department of the Interior \\ KEN SALAZAR, Secretary \\ U.S. Geological Survey \\ Marcia K. McNutt, Director}

U.S. Geological Survey, Reston, Virginia: 2010

This and other USGS information products are available at http://store.usgs.gov/
U.S. Geological Survey
Box 25286, Denver Federal Center
Denver, CO 80225
To learn about the USGS and its information products visit http://www.usgs.gov/
1-888-ASK-USGS

Any use of trade, product, or firm names is for descriptive purposes only and does not imply endorsement by the U.S. Government.

Although this report is in the public domain, permission must be secured from the individual copyright owners to reproduce any copyrighted materials contained within this report.

Suggested citation:

Becker, C.J., 2010, A Reconnaissance of selected organic compounds in streams in tribal lands in Central Oklahoma, January-February 2009: U.S. Geological Survey Scientific Investigations Report 2010-5110, 46 p. (Revised August 2010) 


\section{Contents}

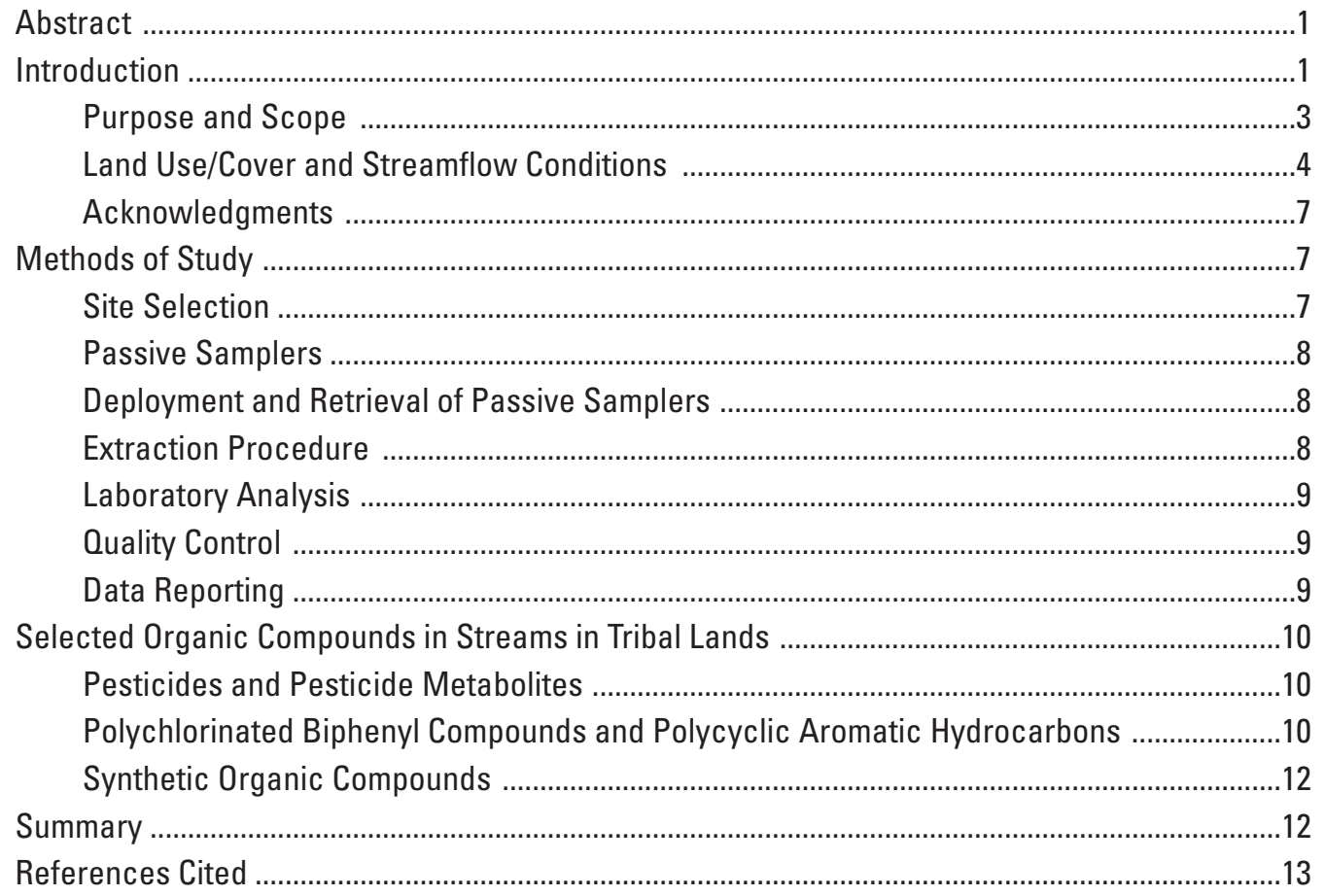

Appendixes

1. Organic compounds as analyzed in extracts from Semipermeable Membrane Devices or Polar Organic Chemical Integrative Samplers for this study, including suspected endocrine disruption potential, Chemical Abstract Service number, possible compound uses or sources, sampler type used to sequester compound, and laboratory method used for analysis

2. Concentrations of pesticides and pesticide metabolites measured in extracts from Semipermeable Membrane Devices submerged at five U.S. Geological Survey stream-gaging stations in jurisdictional areas of several tribes in central Oklahoma, January-February 2009

3. Approximate concentrations of pesticides and pesticide metabolites in water calculated by using performance reference compounds measured in extracts from Semipermeable Membrane Devices submerged at five U.S. Geological Survey stream-gaging stations in jurisdictional areas of several tribes in central Oklahoma, January-February 2009

3. Approximate concentrations of pesticides and pesticide metabolites in water calculated by using performance reference compounds measured in extracts from Semipermeable Membrane Devices submerged at five U.S. Geological Survey stream-gaging stations in jurisdictional areas of several tribes in central Oklahoma, January-February 2009

4. Concentrations of pesticides, pesticide metabolites, polychlorinated biphenyl compounds, polycyclic aromatic hydrocarbons, and other types of synthetic organic compounds measured in extracts from Semipermeable Membrane Devices or Polar Organic Chemical Integrative Samplers submerged at two stream sites on the North Canadian River adjacent to the Kickapoo tribal lands in central Oklahoma, January-February 2009 


\section{Figures}

1-2. Maps showing:

1. Location of U.S. Geological Survey stream-gaging stations and stream sites where passive samplers where submerged in jurisdictional areas of several tribes in central Oklahoma, January-February 2009.

2. Land use/cover in central and western Oklahoma during 2001

3. Hydrographs showing streamflow and precipitation during submergence of passive samplers and historical mean daily streamflow at U.S. Geological Survey stream-gaging stations in jurisdictional areas of several tribes in central Oklahoma, January-February 2009

4-5. Graphs showing:

4. The number of pesticides and pesticide metabolites detected in extracts from Semipermeable Membrane Devices submerged at U.S. Geological Survey stream-gaging stations in jurisdictional areas of several tribes in central Oklahoma, January-February 2009

5. The number of detections of pesticides, pesticide metabolites, polychlorinated biphenyl compounds, polycyclic aromatic hydrocarbons, and other types of synthetic organic compounds measured in extracts from Semipermeable Membrane Devices or Polar Organic Integrative Samplers submerged at two stream sites on the North Canadian River adjacent to the Kickapoo tribal lands in central Oklahoma, January-February 2009

\section{Tables}

1. U.S. Geological Survey stream-gaging stations, stream sites, and sample information for passive samplers submerged in jurisdictional areas of several tribes in central Oklahoma, January-February 2009

2. Historical streamflow statistics and upstream land use/cover for U.S. Geological Survey stream-gaging stations where passive samplers were submerged in jurisdictional areas of several tribes in central Oklahoma, January-February 2009 .......7

\section{Conversion Factors}

\begin{tabular}{|c|c|c|}
\hline Multiply & By & To obtain \\
\hline \multicolumn{3}{|c|}{ Length } \\
\hline inch (in) & 2.54 & centimeter $(\mathrm{cm})$ \\
\hline mile (mi) & 1.61 & kilometer $(\mathrm{km})$ \\
\hline \multicolumn{3}{|c|}{ Area } \\
\hline square mile $\left(\mathrm{mi}^{2}\right)$ & 2.59 & square kilometer $\left(\mathrm{km}^{2}\right)$ \\
\hline \multicolumn{3}{|c|}{ Flow rate } \\
\hline cubic foot per second $\left(\mathrm{ft}^{3} / \mathrm{s}\right)$ & 0.028 & cubic meter per second $\left(\mathrm{m}^{3} / \mathrm{s}\right)$ \\
\hline
\end{tabular}

Laboratory reporting level (LRL) — LRLs are the smallest measured compound concentration that the laboratory could accurately measure for the analytical method used. LRLs were calculated using the lowest equipment calibration standards with the assumption that the 
compound spike had a 100 percent recovery and that there were no interferences from the sample matrix (Duane Wydoski, U.S. Geological Survey, National Water Quality Laboratory, written commun., 2009). The value of the LRL was reported with a "less than" remark code for samples in which the analyte was not detected.

Horizontal coordinate information is referenced to the North American Datum of 1983 (NAD 83).

Concentrations of chemical constituents in water are estimated and given in nanogram of compound per liter of water (ng/L). Compound concentrations measured in extracts are reported in nanogram per ampoule of extract from a composite of three SPMD or three POCIS media in each sampler. 



\title{
A Reconnaissance of Selected Organic Compounds in Streams in Tribal Lands in Central Oklahoma, January- February 2009
}

\author{
By Carol J. Becker
}

\begin{abstract}
The U.S. Geological Survey worked in cooperation with the U.S. Environmental Protection Agency and the Kickapoo Tribe of Oklahoma on two separate reconnaissance projects carried out concurrently. Both projects entailed the use of passive samplers as a sampling methodology to investigate the detection of selected organic compounds at stream sites in jurisdictional areas of several tribes in central Oklahoma during January-February 2009.

The focus of the project with the U.S. Environmental Protection Agency was the detection of pesticides and pesticide metabolites using Semipermeable Membrane Devices at five stream sites in jurisdictional areas of several tribes. The project with the Kickapoo Tribe of Oklahoma focused on the detection of pesticides, pesticide metabolites, polycyclic aromatic hydrocarbons, polychlorinated biphenyl compounds, and synthetic organic compounds using Semipermeable Membrane Devices and Polar Organic Chemical Integrative Samplers at two stream sites adjacent to the Kickapoo tribal lands. The seven stream sites were located in central Oklahoma on the Cimarron River, Little River, North Canadian River, Deep Fork, and Washita River.

Extracts from SPMDs submerged at five stream sites, in cooperation with the U.S. Environmental Protection Agency, were analyzed for 46 pesticides and 6 pesticide metabolites. Dacthal, a pre-emergent herbicide, was detected at all five sites. Pendimethalin, also a pre-emergent, was detected at one site. The insecticides chlorpyrifos and dieldrin were detected at three sites and $p, p^{\prime}$-DDE, a metabolite of the insecticide DDT, also was detected at three sites.
\end{abstract}

SPMDs and POCIS were submerged at the upstream edge and downstream edge of the Kickapoo tribal boundaries. Both sites are downstream from the Oklahoma City metropolitan area and multiple municipal wastewater treatment plants. Extracts from the passive samplers were analyzed for 62 pesticides, 10 pesticide metabolites, 3 polychlorinated biphenyl compounds, 35 polycyclic aromatic hydrocarbons, and 49 synthetic organic compounds.
Ten pesticides and four pesticide metabolites were detected at the upstream site and seven pesticides and four pesticide metabolites were detected at the downstream site. Pesticides detected at both sites were atrazine, chlorpyrifos, dacthal, dieldrin, metolachlor, pendimethalin, and transnonachlor. Additionally at the upstream site, heptachlor, pentachlorophenol, and prometon were detected. The pesticide metabolites $p, p^{\prime}$-DDE, cis-chlordane, and trans-chlordane also were detected at both sites.

Polychlorinated biphenyl compounds aroclor-1016/1242, aroclor-1254, and aroclor-1260 were detected at both sites. The upstream site had 16 polycyclic aromatic hydrocarbon detections and the downstream site had 8 detections. Because of chromatographic interference during analysis, a positive identification of 17 polycyclic aromatic hydrocarbons could not be made. Consequently, there may have been a greater number of these compounds detected at both sites.

A total of 36 synthetic organic compounds were detected at the two sites adjacent to the Kickapoo tribal lands. The upstream site had 21 synthetic organic compound detections: three detergent metabolites, two fecal indicators, three flame retardants, seven industrial compounds, five compounds related to personal care products, and beta-sitosterol, a plant sterol. Fifteen synthetic organic compounds were detected at the downstream site and included: one fecal indicator, three flame retardants, six industrial compounds, and five compounds related to personal care products.

\section{Introduction}

Sovereign tribal lands encompass a large part of central Oklahoma (fig. 1). The gathering of aquatic plants and animals and particularly fish for consumption from streams is a common cultural practice with tribal members. Pesticides and other types of synthetic organic compounds (SOCs) are a concern to tribal members and the people who use streams as a source of food and recreation. 

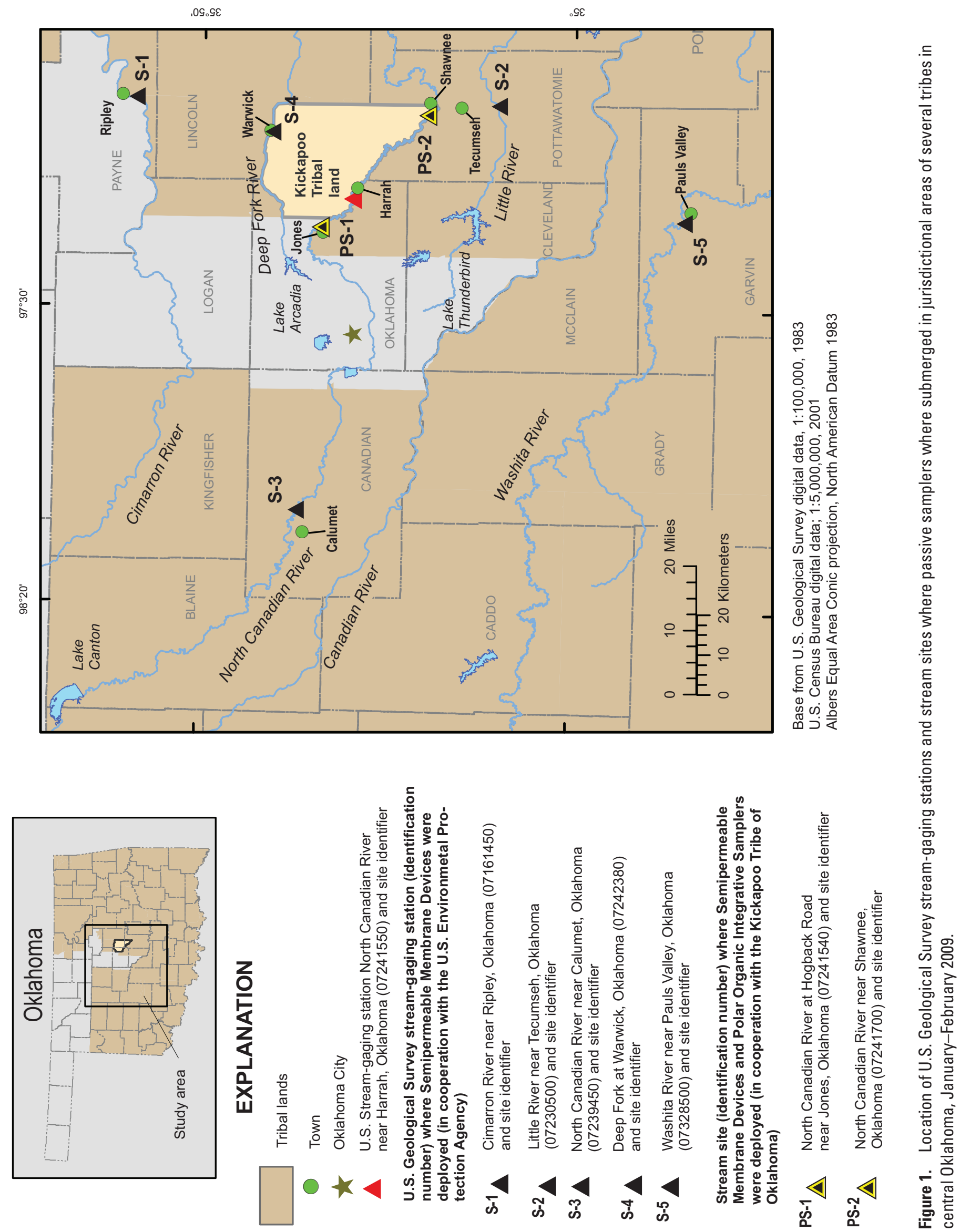
A wide variety of SOCs are used today in agriculture, pharmaceuticals, chemical manufacturing, and personal care products. These compounds may enter streams in surfacewater runoff from agricultural and urban land-use areas and in treated wastewater effluent from municipal wastewater treatment plants. The detection and types of SOCs in groundwater and surface water have been the focus of many studies over the last decade (Galloway and others, 2004; Masoner and Mashburn, 2004; Tertuliani and others, 2008). The frequency with which these compounds are detected in streams was shown by Kolpin and others (2002) in a study that found 80 percent of 139 streams sampled across the United States had detectable concentrations. Many of these compounds are suspected or are known endocrine disruptors that can influence or interfere with the hormonal system of growing organisms (Rhomberg and Seeley, 2005; Tulane and Xavier Universities, 2009a) causing reproductive and developmental problems. In humans, the potential health effects are debatable, but research has shown that the consumption of low concentrations of SOCs or mixtures can contribute to female reproductive disorders (Crain and others, 2008). There also is speculation of other health concerns, especially to growing embryos and fetuses (Tulane and Xavier Universities, 2009b).
In an effort to look more closely at pesticides and other types of SOCs in streams in Oklahoma, the U.S. Geological Survey (USGS) Oklahoma Water Science Center worked in cooperation with the U.S. Environmental Protection Agency (US EPA) and the Kickapoo Tribe of Oklahoma on two separate but similar reconnaissance projects carried out concurrently. Both projects entailed the use of passive samplers, Semipermeable Membrane Devices (SPMD) and Polar Organic Chemical Integrative Sampler (POCIS) as a surfacewater sampling methodology to detect SOCs.

\section{Purpose and Scope}

The purpose of this report is to describe the results from a reconnaissance of selected organic compounds in streams, performed from January 15 through February 19, 2009 that used passive samplers at seven stream sites in jurisdictional areas of several tribes (fig. 1 and table 1).

In cooperation with the Kickapoo Tribe of Oklahoma, SPMDs and POCIS were submerged at two stream sites, referred to as PS-1 and PS-2, on the North Canadian River in Oklahoma and Pottawatomie counties adjacent to the

Table 1. U.S. Geological Survey stream-gaging stations, stream sites, and sample information for passive samplers submerged in jurisdictional areas of several tribes in central Oklahoma, January-February 2009.

[USGS, U.S. Geological Survey; POCIS, Polar Organic Chemical Integrative Sampler; SPMD, Semipermeable Membrane Device; PAH, polycyclic aromatic hydrocarbon; PCB, polychlorinated biphenyl compound; SOC, synthetic organic compound]




Kickapoo tribal lands (fig. 1). Sites PS-1 and PS-2 were about 9 miles upstream and about 24 miles downstream, respectively, from the USGS stream-gaging station North Canadian River near Harrah, Oklahoma (fig. 1 and table 1). Extracts from the POCIS and SPMDs deployed at PS-1 and PS-2, were analyzed for 62 pesticides, 10 pesticide metabolites, 3 polychlorinated biphenyl compounds (PCB), 35 polycyclic aromatic hydrocarbons (PAH), and 49 SOCs by using the laboratory methodologies described by Noriega and others (2004) and Zaugg and others (1995; 2006; 2007). Nine pesticides, one metabolite, and eight PAHs were analyzed by using more than one laboratory methodology.

In cooperation with the US EPA, SPMDs were submerged at five stream sites, referred to as S-1 through S-5, located at USGS stream-gaging stations; Cimarron River near Ripley, Oklahoma (07161450), Little River near Tecumseh, Oklahoma (07230500), North Canadian River near Calumet, Oklahoma (07239450), Deep Fork at Warwick, Oklahoma (07242380), and the Washita River near Pauls Valley, Oklahoma (07328500) in Payne, Pottawatomie, Canadian, Lincoln, and Garvin counties (respectively) in central Oklahoma (fig. 1 and table 1). Extracts from the SPMDs were analyzed for 46 pesticides and 6 pesticide metabolites by using the laboratory methodology described in Zaugg and others (1995) (appendixes 1 and 2). Approximate concentrations in water were calculated for the pesticides and pesticide metabolites and are shown in appendix 3.

\section{Land Use/Cover and Streamflow Conditions}

Land use/cover has an effect on the types and frequencies of pesticides detected in surface water. USGS studies between 1992 and 2001 showed that pesticides were most frequently detected in agricultural and urban areas and the types detected were primarily those with the greatest use (Gilliom and others, 2006). Streams in urban areas had higher detections of insecticides and herbicides used for nonagricultural purposes. Pesticides that were most frequently detected in agricultural and urban areas were atrazine, metolachlor, prometon, and simazine, and the atrazine metabolite deethylatrazine.

Land use/cover varies in Oklahoma from grassland and agriculture in the west to hay/pasture and forest in the east (fig. 2). The greatest density of urban development in the study area is in Oklahoma County in and surrounding Oklahoma City.

In agricultural areas, cultivated crops are dominated by the production of wheat, with alfalfa, sorghum, and other small grain crops grown in smaller amounts. Pesticides are generally applied during the growing season from spring to autumn to control weeds, insects, and fungus on crops. Correspondingly, pesticides are a much greater concern in streams and groundwater during these times of the year. Pesticide use during winter is negligible in Oklahoma, but pre-emergent herbicides are used occasionally to deter the growth of winter grasses for the wheat spring growing season (Brad Tipton, Canadian County
Agriculture Educator, written commun., 2008). Herbicides commonly applied for weed control during the winter months in Canadian County are sulfonylurea compounds which were not analyzed in this study.

Grassland covers the largest percentage of land in the upstream basins for five of the six gages, including the Harrah gage near sites PS-1 and PS-2 (table 2). Upstream from the Tecumseh gage, deciduous forest covers the largest percentage of land and grassland the second. Cultivated crops are the second largest land use in the upstream basins of the Ripley, Calumet, Harrah, and Pauls Valley gages. Urban development is the third largest land use upstream from the Tecumseh, Harrah, and Warwick gages making up 11, 4, and 16, percent, respectively.

The Ripley gage at S-1 has the largest upstream drainage area of 17,979 square miles $\left(\mathrm{mi}^{2}\right)$ and the largest annual mean streamflow of 2,236 cubic feet per second $\left(\mathrm{ft}^{3} / \mathrm{s}\right)$ during the period of record 1988 to 2008 (table 2). The Tecumseh gage at S-2 has the smallest upstream drainage area of $456 \mathrm{mi}^{2}$ and the smallest annual mean streamflow of $146 \mathrm{ft}^{3} / \mathrm{s}$ (period of record 1965 to 2009). Streamflow data are available from the USGS National Water Information System website, http://waterdata.usgs.gov/nwis.

The Calumet gage, at S-3 has an upstream drainage area of $12,962 \mathrm{mi}^{2}$ and an annual mean streamflow of $268 \mathrm{ft}^{3} / \mathrm{s}$ during the period of record 1988 to 2008 (table 2). An increase in streamflow, not related to precipitation, is periodically measured at the Calumet gage as a result of releases from Lake Canton about 60 miles upstream. The effect on streamflow from a release can be seen on figure 3 beginning on February 15 , as an increase from $80 \mathrm{ft}^{3} / \mathrm{s}$ to $250 \mathrm{ft}^{3} / \mathrm{s}$ about 4 days before the passive sampler was retrieved.

The Warwick gage at S-4, has the second smallest drainage area of $532 \mathrm{mi}^{2}$ and the second smallest annual mean streamflow of $260 \mathrm{ft}^{3} / \mathrm{s}$, during the period of record 1988 to 2008 (table 2). The headwaters of the basin upstream from the Warwick gage begin in the northern parts of the Oklahoma City metropolitan area and flow into Lake Arcadia, which is the primary source of streamflow to the Deep Fork (fig. 1). Streamflow periodically increases because of releases from Lake Arcadia. The effects on streamflow are shown on figure 3 , as an increase of about $60 \mathrm{ft}^{3} / \mathrm{s}$ beginning on February 23, 2009 about 4 days after the passive sampler was retrieved.

The Harrah station, near sites PS-1 and PS-2, has an upstream drainage area of 13,501 $\mathrm{mi}^{2}$ and an annual mean streamflow of $500 \mathrm{ft}^{3} / \mathrm{s}$ during the period of record 1969 to 2008 (table 2). Streamflow on the North Canadian River near the Harrah gage is periodically affected by water released from upstream reservoirs and from a series of low-water weirs adjacent to Oklahoma City. Streamflow also may be affected by periodic releases of treated effluent from multiple upstream municipal wastewater treatment plants, but the magnitude of these effects is unknown. Releases from upstream reservoirs are apparent on figure 3 as an increase in streamflow beginning on February 19. 






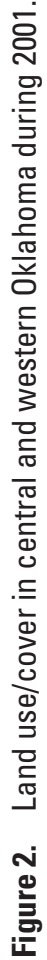



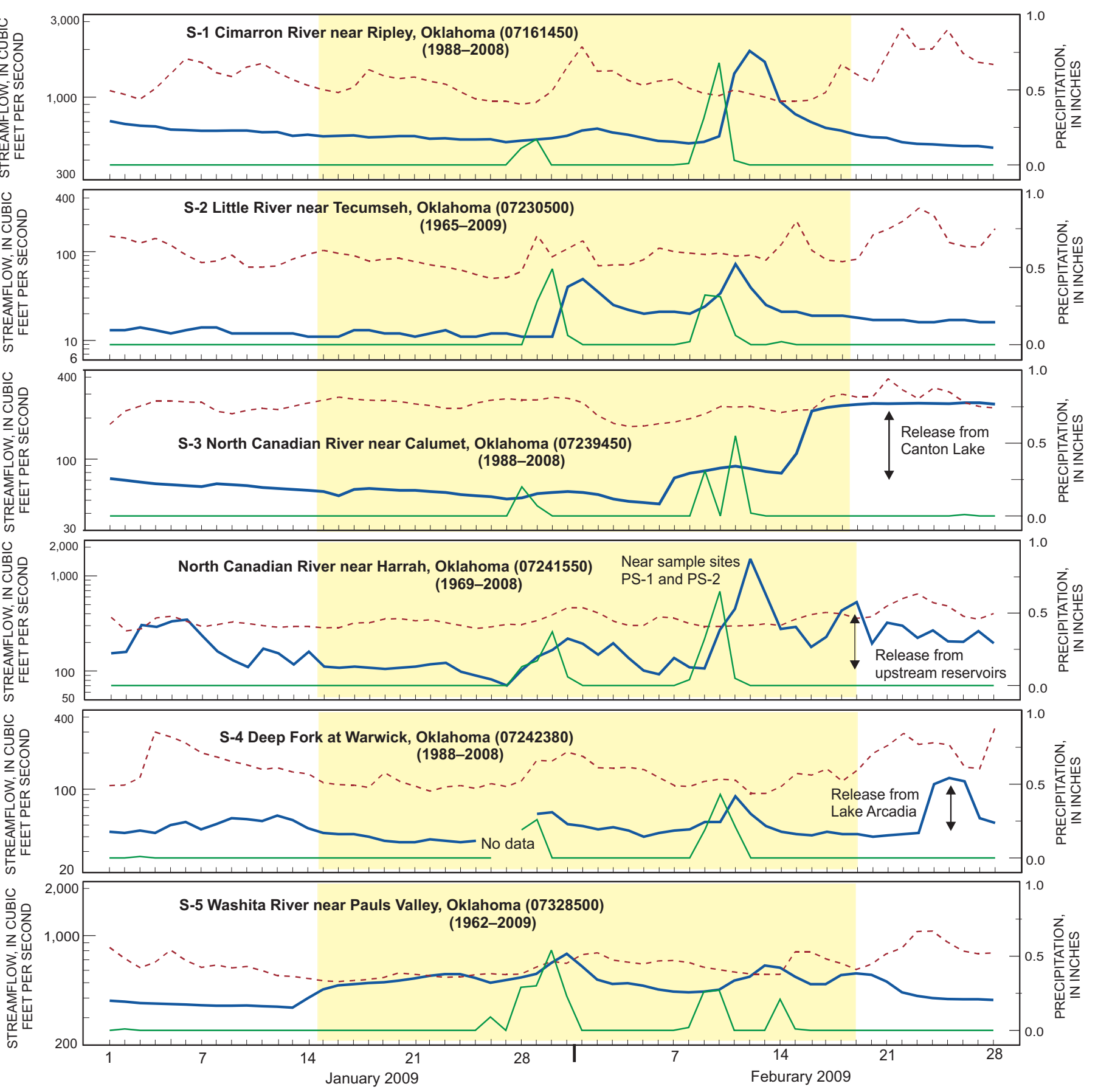

EXPLANATION

Time period during which passive samplers were submerged
Precipitation, in inches

Streamflow, in cubic feet per second

(1988-2009) Mean daily streamflow, in cubic feet per second, for period of record (see table 2)

Figure 3. Hydrographs showing streamflow and precipitation during submergence of passive samplers and historical mean daily streamflows at U.S. geological Survey streamflow-gaging stations in jurisdictional areas of several tribes in central Oklahoma, January-February 2009. 
Table 2. Historical streamflow statistics and upstream land use/cover for U.S. Geological Survey stream-gaging stations where passive samplers were submerged in jurisdictional areas of several tribes in central Oklahoma, January-February 2009.

[USGS, U.S. Geological Survey; $\mathrm{ft}^{3} / \mathrm{s}$, cubic feet per second; $\mathrm{mi}^{2}$, square miles]

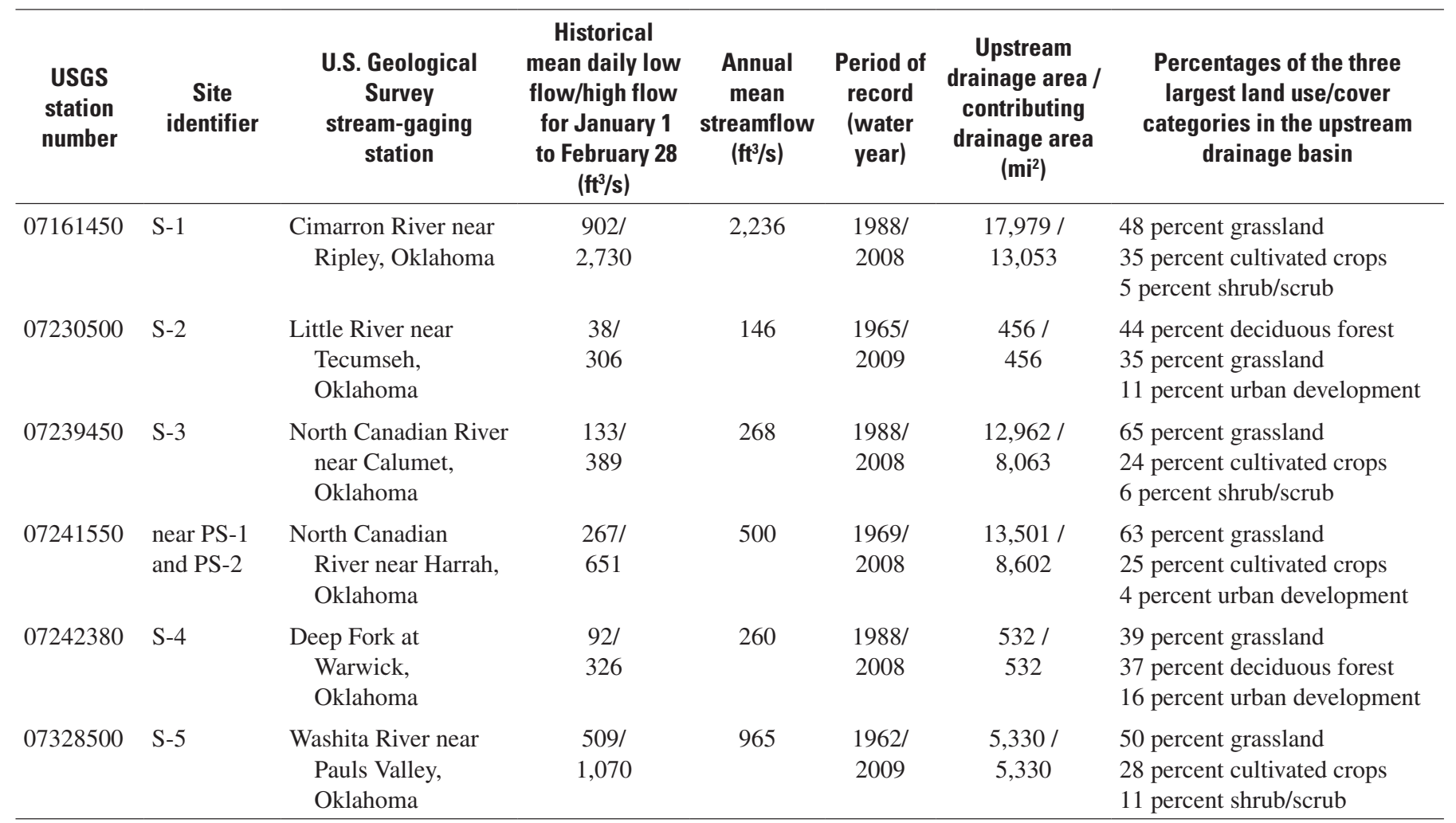

\section{Acknowledgments}

The author would like to thank Genevieve McGeisey and Darren Shields with the Kickapoo Tribe of Oklahoma for their assistance with the project. Appreciation also is given to Chad Ashworth, Mark Becker, Rick Hanlon, Stan Paxton, Ernie Smith, and Kim Winton at the USGS Oklahoma Water Science Center for their assistance with the project. The advice and guidance provided by Duane Wydoski at the USGS National Water Quality Laboratory in Denver, Colorado was invaluable. Thanks are given to Jason Masoner with the USGS Oklahoma Water Science Center and David Alvarez with the USGS Columbia Environmental Research Center for their peer reviews of the manuscript.

\section{Methods of Study}

SPMDs were deployed at all seven stream sites S-1 through S-5 and PS-1 and PS-2. POCIS were deployed, in addition to SPMDs, at stream sites PS-1 and PS-2. Both types of passive samplers were submerged in streams from January 15 through February 19 during low flow, when streamflow conditions generally were less than the daily mean flow for the period of record.
The SPMD and POCIS passive samplers have several advantages over surface-water grab samples. Passive samplers provide water-quality information during an integrated period of time, usually weeks, and during a range of hydrologic conditions. In contrast, grab samples are collected at a single point and only provide site-specific water-quality information for a snapshot in time. The extended exposure time of the passive samplers to water increases the likelihood of detecting constituents that might be in the stream only intermittently (Alvarez and others, 2004). Additionally, the SPMD media sequester chemicals similarly to aquatic biota and can provide information about the bioavailability of hydrophobic chemicals in streams not typically measured in water samples (Environmental Sampling Technologies, 2008).

\section{Site Selection}

Stream sites S-1 through S-5 were at USGS streamgaging stations; whereas, PS-1 and PS-2 were near bridges about 9 miles upstream and about 24 miles downstream (respectively) from the stream-gaging station North Canadian River near Harrah, Oklahoma, (07241550) (fig. 1 and table 2). Sample sites PS-1 and PS-2 were selected on the upstream and downstream boundaries of the Kickapoo tribal land. Multiple upstream wastewater treatment plants (2009) are permitted to 
discharge treated wastewater effluent into the North Canadian River (Oklahoma Department of Environmental Quality, 2009) upstream from the Kickapoo tribal boundary (fig. 1). The PS-1 sample site was at the western edge of the tribal boundary upstream from areas used by the tribe for ceremonies. Samplesite PS-2 was established downstream on the eastern edge of the tribal boundary to detect pesticides and other types of SOCs leaving the tribal jurisdictional area.

Deployment sites were selected where stream depth and flow were adequate for the entire period of submergence. The sampler had to remain submerged in moving water and placed so it could be safely deployed and retrieved during high flow, if necessary. The sampler also needed to be where the chance of floating debris and vandalism were minimal.

\section{Passive Samplers}

Three SPMDs in a canister were deployed at each stream site. Each SPMD consisted of lipid-filled polyethylene tubing, 91.4 centimeters long and 2.5 centimeters wide, wound around posts on a support rack to maximize surface exposure. The polyethylene tubing has transport properties that selectively allow hydrophobic compounds in water to partition into the SPMD and be retained by the membrane and a thin film of triolein (lipid). The lipid and membrane collectively sequesters the compounds that are later extracted and analyzed (Environmental Sampling Technologies, 2008).

The triolein was spiked before deployment with four polychlorinated biphenyl compounds (PCB-4, 14, 29, and 50) that were used as performance reference compounds (PRC). As described in detail by Huckins and others (2006) and Tertuliani and others (2008) the PRCs provide an estimate of SPMD sampling rates at each sample site, which varies depending on environmental factors such as temperature, water velocity, and membrane biofouling. The rate of PRC loss from the SPMD membranes during stream submergence was compared to that of the PRC loss during laboratory calibration studies to derive an exposure adjustment factor, which was used to determine more accurate in situ sampling rates. This information was used in combination with SOC partition coefficients and concentrations measured in sample extracts to estimate timeweighted water concentrations by using the exposure models created by Huckins and others (2006) and the U.S. Geological Survey, Columbia Environmental Research Center (2006).

Three POCIS in a canister were deployed only at stream sites PS-1 and PS-2. Each POCIS is composed of sorbent materials enveloped by a microporous polyethersulfone membrane. The membrane allows dissolved constituents to flow through and be sequestered while filtering out sediment and debris (U.S. Geological Survey, Columbia Environmental Research Center, 2004). The POCIS was used to sample for dissolved SOCs that included selected pesticides, detergent metabolites, fecal indicators, flame retardants, industrial compounds, and compounds related to personal care products (appendix 1). The compounds were later extracted from the sorbent and analyzed.

\section{Deployment and Retrieval of Passive Samplers}

The SPMDs and POCIS were purchased from Environmental Sampling Technologies, St. Joseph, Missouri, and were sent to the USGS Oklahoma Water Science Center surrounded by argon gas in sealed metal cans. The cans containing the SPMDs were kept at $-20^{\circ}$ Celsius until the day of deployment and then chilled on ice until submergence at the deployment sites.

During deployment the SPMDs and POCIS media, preloaded on support racks, were removed from the original metal cans and placed in a protective stainless steel canister as quickly as possible. The support racks were handled with clean gloved hands and SPMD and POCIS surfaces were not touched or abraded. USGS personnel refrained from the use of personal care products and caffeine on the day of deployment.

Canisters at six stream sites were secured to T-posts with a length of stainless steel chain and one canister was secured to the bridge. During retrieval, canisters were moved from the water and the passive samplers on the support racks were removed and returned to the original metal cans, sealed, and placed on ice. The sealed cans were transported back to USGS Oklahoma Water Science Center and were stored at $-20^{\circ}$ Celsius until being placed on ice and shipped overnight to Environmental Sampling Technologies for extraction.

\section{Extraction Procedure}

The sequestered SOCs were extracted from the SPMDs and POCIS by Environmental Sampling Technologies. SOCs in the POCIS were extracted with 40 milliliters of methanol and concentrated under ultra high purity nitrogen. The extracts were transferred to methanol, filtered through a glass fiber filter (Fisher, G-6) and quantitatively transferred to 2-milliliter amber ampoules (Terri Spencer, Environmental Sampling Technologies, written commun., 2009).

Briefly, SOCs and performance reference compounds were extracted from the SPMDs by dialysis in hexane, concentrated by using the Kuderna-Danish method (Dean, 2010), reduced in volume under ultra high purity nitrogen to about 0.5 milliliter, and then filtered through a glass fiber filter (Fisher, G-6) by using methylene chloride. Sample volumes were again reduced under ultra high purity nitrogen and quantitatively transferred to auto sampler vials by using methylene chloride as the transfer solvent. Samples underwent final clean-up by gel permeation chromatography, were again reduced in volume with ultra high purity nitrogen, and quantitatively transferred with methylene chloride to 2-milli- 
liter amber ampoules (Terri Spencer, Environmental Sampling Technologies, written commun., 2009).

The final SPMD and POCIS extracts for each sampling site were a composite of the three samplers in a canister for each sampler type. Similarly, the field blanks were combined into an extract for each sampler type.

\section{Laboratory Analysis}

SPMD and POCIS extracts were analyzed by the USGS National Water Quality Laboratory (NWQL) in Lakewood, Colorado using custom methodologies (Duane Wydoski, U.S. Geological Survey, National Water Quality Laboratory, written commun., 2009). SPMD extracts from the sites S-1 through S-5 and PS-1 and PS-2 were analyzed for 46 pesticides and 6 pesticide metabolites by using the technique described in Zaugg and others (1995). The methylene chloride solvent containing the extracts was replaced by a mixture of ethyl acetate and toluene. The solvent mixture was then analyzed by using gas chromatography/mass spectrometry by positive ion electron-impact ionization in the selected-ion mode. Each compound was identified in the extract by comparing curves to analytical standards and National Institute of Science and Technology reference spectra. The compound concentration in the extract was determined by using a six-point curve based on calibration that was normalized to internal standards.

A portion of the PS-1 and PS-2 SPMD extracts was replaced with hexane and analyzed for 14 pesticides, 4 pesticide metabolites and 3 PCB compounds by using the technique described in Noriega and others (2004) (appendix 4). The extracts were cleaned by using alumina/silica combined column adsorption chromatography and were split into two fractions. The second fraction underwent an additional adsorption chromatography step by using a Florisil column for cleanup. Both fractions were analyzed by dual capillarycolumn gas chromatography with electron-capture detection that was calibrated for both capillary columns by using multipoint calibration standards. The compound concentrations in the extracts were determined by using a six-point curve based on calibration standards that were normalized to internal standards.

SPMD extracts from PS-1 and PS- 2 also were analyzed for 2 pesticides, $32 \mathrm{PAHs}$, and 4 SOCs (appendixes 1 and 4) and performance reference compounds by using the instrumental conditions described in Zaugg and others (2006). The extracts in methylene chloride were analyzed by using gas chromatography/mass spectrometry by positive ion electron-impact ionization in the selected-ion mode. Each compound was identified in the extract by comparing curves to analytical standards and National Institute of Science and Technology reference spectra. Compound concentration in the extract was determined by using a six-point curve based on calibration standards that were normalized to internal standards.
POCIS extracts from PS- 1 and PS-2 were analyzed for 8 pesticides, 11 PAHs, and 43 SOCs, many of which are considered indicators of wastewater effluent (appendixes 1 and 4), by using the technique and instrumental conditions described in Zaugg and others (2007). The extracts in methylene chloride, in addition to a set of multiple-level analytical standard solutions, were analyzed by full scan positive-ion gas chromatography/mass spectrometry in the electron-impact mode.

\section{Quality Control}

Quality control blanks were used to assess unintentional contamination in the field and in the laboratory. A field blank consisting of three SPMDs was processed with the SPMDs deployed at sites S-1 through S-5. A second field blank consisting of three SPMDs and three POCIS was processed with samplers deployed at PS-1 and PS-2.

Laboratory blanks and spikes were used by NWQL to assess the preparation, analyte recovery, and to check the performance of the analytical methods. Field and laboratory blanks and spike information are shown on appendixes 2 and 4 .

\section{Data Reporting}

The detection or nondetection of a compound is used for descriptive and comparative purposes in the report and not the laboratory or calculated water concentrations. A compound was considered detected if it was measured in the extract at a concentration three times, or greater, than the highest concentration measured in the field or laboratory blank.

Compound concentrations measured in extracts are reported in nanogram per ampoule of extract from a composite of three SPMD or three POCIS media in each sampler. These extract concentrations are shown in appendixes 2 and 4. Approximate water concentrations in nanogram per liter (ng/L) were calculated for selected pesticides, PCB compounds, and PAHs (appendixes 3 and 4).

Compound concentrations are reported above the laboratory reporting level which is the smallest measured compound concentration that the laboratory could accurately measure for the analytical method used. Laboratory reporting levels were calculated by using the lowest equipment calibration standards with the assumption that the compound spike had a 100 percent recovery with no interferences from the sample matrix (Duane Wydoski, U.S. Geological Survey, National Water Quality Laboratory, written commun., 2009).

The presence of many compounds could not be positively identified at less than the laboratory reporting level because of chromatographic interference during analysis at the laboratory. These concentrations are preceded by a less than sign $(<)$ and are considered nondetections. 
Seventeen compounds were analyzed in the SPMD and POCIS extracts from PS-1 and PS-2 by two different laboratory methodologies. Dieldrin and $p, p^{\prime}$-DDE were the only compounds detected in both sampler extracts; both compounds are counted only once as a detection in the report.

\section{Selected Organic Compounds in Streams in Tribal Lands}

Extracts from the SPMDs deployed at S-1 through S-5 were analyzed for 46 pesticides and 6 pesticide metabolites (appendix 2). Extracts from the POCIS and SPMDs deployed at PS-1 and PS-2, were analyzed for, 10 pesticide metabolites, 3 PCBs, 35 PAHs, and 49 SOCs. Nine pesticides, one pesticide metabolite, and eight PAHs were analyzed in extracts from samplers deployed at the two sites by using more than one laboratory methodology. Approximate concentrations in water were calculated for selected pesticides and pesticide metabolites and are shown in appendixes 3 and 4.

\section{Pesticides and Pesticide Metabolites}

Sites S-1 through S-5 had one to four pesticides detected of the 46 analyzed in SPMD extracts (fig. 4). Sites PS- 1 and PS-2 had 10 and seven pesticides detected, respectively, of the 62 pesticides analyzed in extracts from both sampler types (fig. 5 and appendix 4). All seven sites had detections of dacthal, a preemergent herbicide. Three sites, PS-1, PS-2, and S-4 also had detections of pendimethalin, a pre-emergent herbicide. Five sites (excluding S-2 and S-3) had detections of the insecticides dieldrin and chlorpyrifos. Chlorpyrifos, commonly called Dursban, was banned for domestic use in June 2000 but is still used for agriculture, wood treatment, and on golf courses (U.S. Environmental Protection Agency, 2002b). Five sites had detections of $p, p^{\prime}$-DDE, a metabolite of the insecticide DDT. Dieldrin and DDT are organochlorine pesticides that were banned in the U.S. more than 20 years ago and are referred to as legacy pesticides because of persistence and widespread detection in the environment (Gilliom and others, 2006),

In addition to the four pesticides detected at S-1 through S-5, the herbicides atrazine, metolachlor, pentachlorophenol, and prometon and the insecticides heptachlor and transnonachlor were detected at PS-1; atrazine, metolachlor, and trans-nonachlor also were detected at PS-2. The pesticide metabolites, cis-chlordane and trans-chlordane, of the legacy insecticide chlordane, also were detected at sites PS-1 and PS-2. These pesticides and pesticide metabolites, except for dacthal, metolachlor, and prometon, are suspected or are known to have endocrine disruptor potential (Kegley and others, 2008).

Concentrations of three detected pesticides and one metabolite are regulated in public-drinking water by the US
EPA with maximum contaminant levels (MCLs) of atrazine (3,000 ng/L), heptachlor (400 ng/L), heptachlor epoxide (200 ng/L), and pentachlorophenol (1,000 ng/L) (U.S. Environmental Protection Agency, 2009a). All four compounds have potential health effects from ingestion ranging from reproduction problems to an increased risk of cancer (U.S. Environmental Protection Agency, 2009a). However, based on SPMD results, the approximate water concentrations of heptachlor and heptachlor epoxide representing stream samples are small, about 2,000 to 4,000 times smaller than the respective MCLs in drinking water. The water concentrations of atrazine and pentachlorophenol could not be estimated because these two compounds were sequestered by the POCIS sampler, which did not have PRCs needed for the calculations.

Increases in concentrations of many water-quality constituents were detected in the downstream direction of the North Canadian River from the Calumet station to the Harrah station by Brigham and others (2002). A summary of water-quality data from 1988 to 1999 showed that while specific conductance and concentrations of dissolved solids and sulfate decreased in the downstream direction, chloride, total dissolved concentrations of nitrogen and phosphorus compounds, and many pesticides increased in the downstream direction. Increases in chloride and nutrient concentrations may be related to effluent from wastewater treatment plants but also can result from urban runoff or natural sources. Brigham and others (2002) reported that the frequencies of detection for 12 of 13 pesticides increased between the Calumet gage and the Harrah gage. Pesticides having the highest frequencies of detection (in 44 to 63 samples) at the Harrah gage were the herbicides 2,4-D (83 percent), atrazine (17 percent), and simazine(67 percent), and the insecticides diazinon ( 90 percent), dieldrin ( 82 percent), and lindane (96 percent). The frequencies of detection ranged from 77 percent for atrazine and 96 percent for lindane.

Brigham and others (2002) reported that the herbicide 2,4-D and the insecticide lindane were the most frequently detected pesticides in stream samples collected at four sites on the North Canadian River from 1988 to 1999. Atrazine and dieldrin were detected at sites PS-1 and PS-2 (near the Harrah gage), whereas, diazinon, lindane, and simazine were not. 2,4-D was not analyzed in this study.

Nationwide, Gilliom and others (2006) reported that USGS studies from 1992 to 2001 showed that the pesticides most frequently detected in streams draining agricultural and urban areas were the herbicides atrazine, metolachlor, prometon, and simazine, and the metabolite of atrazine, deethylatrazine. None of these compounds were detected at sites S-1 through S-5. At sites PS-1 and PS-2, atrazine and metolachlor were detected in addition to prometon, a nonagricultural herbicide, at PS-1. 


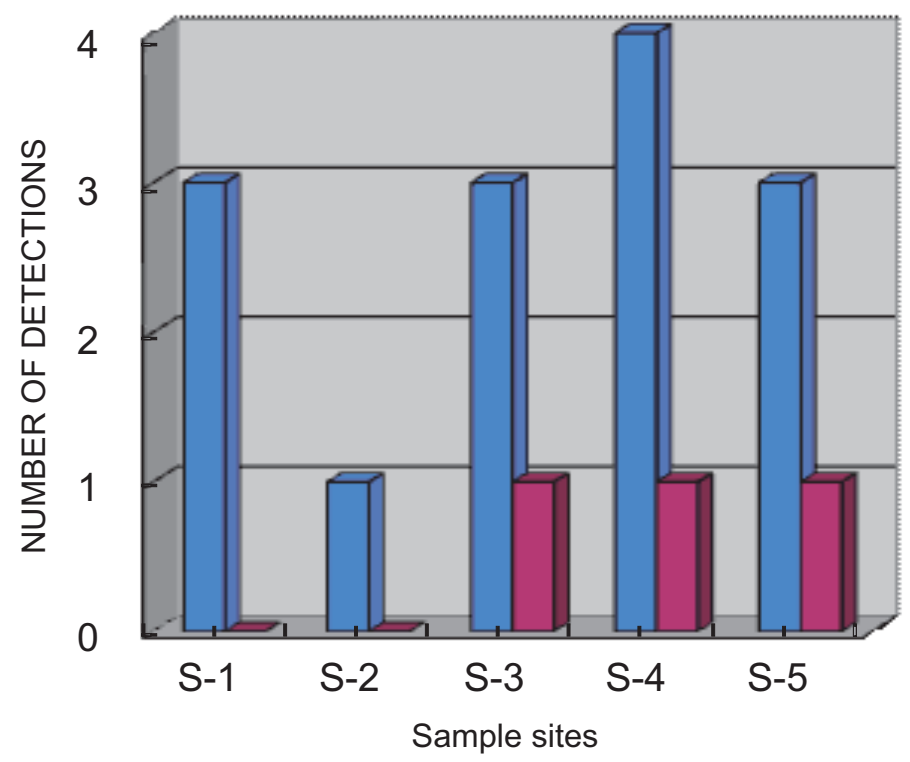

\section{EXPLANATION}

Metabolite

Pesticide

U.S. Geological Survey stream-gaging stations where Semipermeable Membrane Devices were submerged

S-1 Cimarron River near Ripley, Oklahoma (07161450)

S-2 Little River near Tecumseh, Oklahoma (07230500)

S-3 North Canadian River near Calumet, Oklahoma (07239450)

S-4 Deep Fork at Warwick, Oklahoma (07242380)

S-5 Washita River near Pauls Valley, Oklahoma (07328500)

Figure 4. The number of pesticides and pesticide metabolites detected in extracts from Semipermeable Membrane Devices submerged at U.S. Geological Survey stream-gaging stations in jurisdictional areas of several tribes in central Oklahoma, JanuaryFebruary 2009.

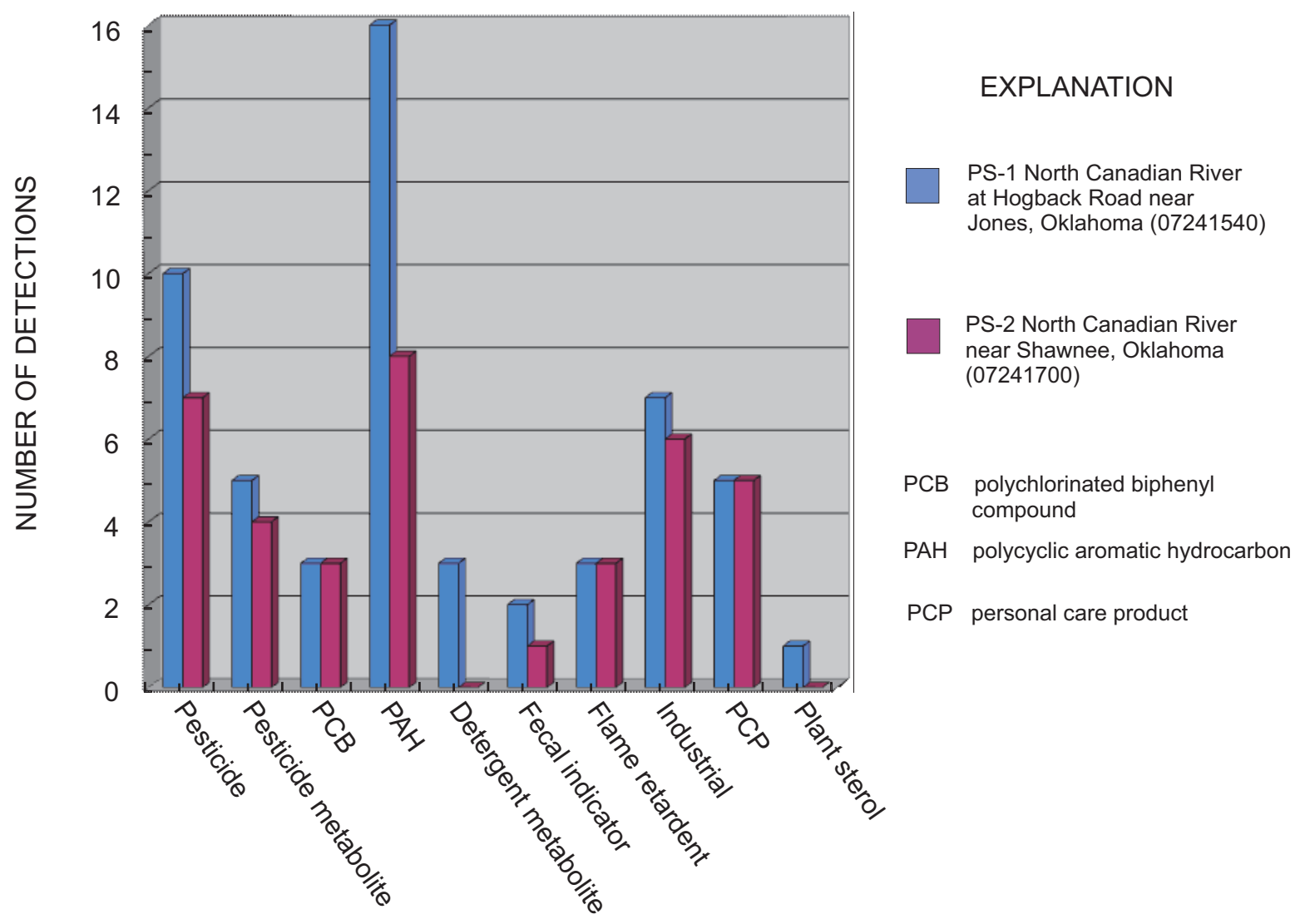

Figure 5. The number of detections of pesticides, pesticide metabolites, polychlorinated biphenyl compounds, polycyclic aromatic hydrocarbons, and other types of synthetic organic compounds measured in extracts from Semipermeable Membrane Devices or Polar Organic Integrative Samplers submerged at two stream sites on the North Canadian River adjacent to the Kickapoo tribal lands in central Oklahoma, January-February 2009. 


\section{Polychlorinated Biphenyl Compounds and Polycyclic Aromatic Hydrocarbons}

Sites PS-1 and PS-2, had detections of the PCB compounds aroclor-1016/1242, aroclor-1254, and aroclor-1260. PCBs were used in many types of industrial applications, such as plasticizers, flame retardants, sealants, dielectric fluids, and adhesives (U.S. Environmental Protection Agency, 2009a). PCBs were banned in 1976, but are still found throughout the environment, as these compounds are persistent and attenuate slowly. The MCL for PCB compounds in drinking water is $5,000 \mathrm{ng} / \mathrm{L}$. The sum of those three compound concentrations approximated in stream water at PS-1 and PS-2 is small, less than $6 \mathrm{ng} / \mathrm{L}$.

PAHs compose a large group of organic compounds that are formed by the incomplete combustion of coal, oil, gas, wood, and other organic substances and are found in the environment in soil, water, or air attached to particulates. Selected PAHs are used in the manufacture of explosives and mothballs, are found in cigarette smoke, and are used in cancer research (U.S. Environmental Protection Agency, 1995).

Site PS- 1 had 16 PAH detections and PS-2 had 8 detections of the 35 PAHs analyzed. Because of chromatographic interference during analysis, a positive identification of 17 PAHs in extracts from PS-1 and 18 in PS-2 could not be made. Consequently, there may have been a greater number of PAH compounds in extracts from these two sites.

Five PAHs only detected at PS-1, benzo(a)anthracene, benzo(b)fluoranthene, benzo(ghi)perylene, benzo(k)fluoranthene, and chrysene, are considered to have endocrine disruption potential (Kegley and others, 2008) and except for benzo(ghi)perylene, are considered probable human carcinogens by the U.S. Environmental Protection Agency (2002a). Fluoranthene and pyrene had the largest approximate concentrations in water of the PAHs detected at PS-1 (12.6 and 12.3 $\mathrm{ng} / \mathrm{L})$ and at PS-2 (6.12 and $5.11 \mathrm{ng} / \mathrm{L})$, respectively. None of the detected PAHs have MCLs for drinking water.

\section{Synthetic Organic Compounds}

SOCs were grouped into five categories on the basis of a common use of the compound; detergent metabolite, fecal indicator, flame retardant, industrial compound, and PCP (fig. 5). Seven SOCs were categorized as industrial because these compounds are used in the manufacture of many types of products, such as pentachloroanisol, which is used in the manufacture of polymers, pesticides, and fire retardants and is also used as a wood preservative. The compound betasitosterol is a natural plant sterol and also is used as a vitamin supplement. This compound was detected at PS-1; however, because the compound is natural, it was not included in the five compound use groups.

Similar to the PAHs, chromatographic interference during laboratory analysis affected the positive identification of SOCs in extracts from both sites. Consequently, the presence of 12
SOCs from PS-1 and 4 SOCs from PS-2 could not be determined. An additional eight SOCs in extracts from PS-2 could not be positively identified most likely because of isopropanol residue from the addition of spike and surrogate solution during the analytical procedure (Duane Wydoski, U.S. Geological Survey, National Water Quality Laboratory, personal commun., 2009)

Sample site PS-1 had 21 SOC detections: 3 detergent metabolites, 2 fecal indicators, 3 flame retardants, 7 industrial compounds, 5 PCPs, and beta-sitosterol (fig. 5). Three detergent metabolites p-nonylphenol, 4-tert-octylphenol diethoxylate, and triclosan; two flame retardants tri(2-chloroethyl) phosphate, and tri(dichlorisopropyl)phosphate; the industrial compound pentachloroanisole, and three PCPs, benzophenone, galaxolide, and tonalide are suspected or are known to be endocrine disruptors.

The 15 SOCs detected at PS-2, downstream from PS-1, were a subset of the 21 detected at PS- 1 and included 1 fecal indicator, 3 flame retardants, 6 industrial compounds, and 5 PCPs. Two of the flame retardants, tri(2-chloroethyl) phosphate and tri(dichlorisopropyl)phosphate; the industrial compound pentachloroanisole and three PCPs, benzophenone, galaxolide, and tonalide are suspected or known to be endocrine disruptors.

Three SOCs having the largest measured concentrations in extracts from PS-1 and PS-2 were 5-methyl-1H-benzotriazole (an antirust and corrosion inhibitor and an antioxidant in antifreeze and deicers), galaxolide (a musk fragrance), and tri(2-butoxyethyl)phosphate (a flame retardant). Galaxolide is the only compound of the three that is known to be an endocrine disruptor. At the time of this report (2010), none of the detected SOCs have MCLs in public drinking-water supplies.

\section{Summary}

The USGS Oklahoma Water Science Center worked in cooperation with the US EPA and the Kickapoo Tribe of Oklahoma on two separate reconnaissance projects carried out concurrently. Both projects entailed the use of passive samplers as a sampling methodology to investigate the detection of selected organic compounds at stream sites in jurisdictional areas of several tribes in central Oklahoma during JanuaryFebruary 2009.

In cooperation with the Kickapoo Tribe of Oklahoma, SPMDs and POCIS were submerged at two sites; one at the upstream western edge (PS-1) and the other at the downstream eastern edge (PS-2) of the Kickapoo tribal boundaries. Both sites are downstream from the Oklahoma City metropolitan area and multiple wastewater treatment plants. Extract composites were analyzed for 62 pesticides, 10 pesticide metabolites, 3 PCBs compounds, 35 PAHs, and 49 SOCs.

Ten pesticides and four pesticide metabolites were detected at the upstream site (PS-1) and seven pesticides and four pesticide metabolites, of 62 pesticides analyzed, were detected at the downstream site (PS-2). Pesticides detected at 
both sites were the herbicides atrazine, dacthal, metolachlor, pendimethalin, and the insecticides chlorpyrifos, dieldrin, and trans-nonachlor. Pesticide metabolites detected at both sites were $p, p^{\prime}$-DDE, and cis-chlordane and trans-chlordane, both pesticide metabolites of the legacy insecticide chlordane. Additionally at the upstream site, the herbicides pentachlorophenol, prometon, and the insecticide heptachlor were detected.

Concentrations of three detected pesticides and one metabolite are regulated in public-drinking water by the US EPA with maximum contaminant levels of atrazine (3,000 ng/L), heptachlor (400 ng/L), heptachlor epoxide (200 $\mathrm{ng} / \mathrm{L})$, and pentachlorophenol (1,000 ng/L). However, the approximate water concentrations of heptachlor and heptachlor epoxide representing stream samples are small, about 2,000 to 4,000 times smaller than the respective maximum contaminant levels in drinking water. The water concentrations of atrazine and pentachlorophenol could not be calculated because these compounds were measured in POCIS extracts.

The PCB compounds aroclor-1016/1242, aroclor-1254, and aroclor-1260 were detected at both sites. The maximum contaminant level for PCBs in drinking water is 5,000 ng/L. The sum of the three compound concentrations approximated in stream water is small, less than $6 \mathrm{ng} / \mathrm{L}$.

The upstream site PS-1 had 16 PAH detections and the downstream site PS-2 had eight detections. Because of chromatographic interference during analysis, a positive identification of 17 PAHs could not be made. Consequently, there may have been a greater number of these compounds in extracts from the two sites. None of the detected PAHs have maximum contaminant levels for public drinking-water supplies.

A total of 36 SOCs were detected at the two sites adjacent to the Kickapoo tribal lands. The upstream site PS-1 had 21 SOC detections; three detergent metabolites, two fecal indicators, three flame retardants, seven industrial compounds, and five compounds related to personal care products. Betasitosterol also was detected. Fifteen SOCs were detected at the downstream site PS-2 and included; one fecal indicator, three flame retardants, six industrial compounds, and five compounds related to personal care products. Similar to the PAHs, chromatographic interference during laboratory analysis affected the positive identification of SOCs in extracts from both sites. Consequently, the presence of 12 SOCs at site PS-1 and four at site PS- 2 could not be determined. An additional eight SOCs in extracts from the downstream site could not be positively identified most likely because of isopropanol residue from the addition of spike and surrogate solution during the analytical procedure.

Three SOCs having the largest measured concentrations in extracts from PS-1 and PS-2 were 5-methyl-1H-benzotriazole (an antirust and corrosion inhibitor and an antioxidant in antifreeze and deicers), galaxolide a musk fragrance, and tri(2-butoxyethyl)phosphate a flame retardant. Galaxolide is the only compound of the three that is known to be an endocrine disruptor. At the time of this report, none of the detected
SOCs have maximum contaminant levels in public drinkingwater supplies.

In cooperation with the US EPA, SPMDs were submerged at five stream sites located at USGS stream-gaging stations on the Cimarron River, Little River, North Canadian River, Deep Fork, and the Washita River. A composite of extracts from three SPMDs submerged at each site was analyzed for 46 pesticides and 6 pesticide metabolites. Dacthal a pre-emergent herbicide was detected at all five sites. Pendimethalin also a pre-emergent was detected at one site. The insecticides chlorpyrifos and dieldrin were detected at three sites and $p, p^{\prime}$-DDE a metabolite of the insecticide DDT also was detected at three sites.

\section{References Cited}

Alvarez, D.A., Petty, J.D., Huckins, J.N., Jones-Lepp, T.L., Getting, D.T., Goddard, J.P., and Manahan, S.E., 2004, Development of a passive, in situ, integrative sampler for hydrophilic organic contaminants in aquatic environments: Environmental Toxicology and Chemistry, v. 23, no. 7, p. 1,640-1,648.

Brigham, Mark E., Payne, Gregory A., Andrews, William J., 2002, Statistical analysis of stream water-quality data and sampling network design near Oklahoma City, central Oklahoma, 1977-1999; U.S. Geological Survey WaterResources Investigations Report 02-4111, 24 p.

Crain, A.D., Janssen, S.J., Edwards, T.M., Heindel, Jerrold, Ho, Shuk-mei, Hunt, Patricia, Iguchi, Taisen, Juul, Anders, McLachlan, J.A., Schwartz, Jackie, Skakkebaek, Niels, Soto, A.M., Swan, Shanna, Walker, Cheryl, Woodruff, T.K., Woodruff, T.J., Giudice, L.C., and Guillette, Louis, Jr., 2008, Female reproductive disorders-The roles of endocrine-disrupting compounds and developmental timing: Fertility and Sterility, v. 90, no. 4, p. 911-940.

Dean, John R., 2010, Extraction techniques in analytical sciences, Chapter 1, Pre- and post-extraction considerations: West Sussex, United Kingdom, John Wiley \& Sons, Ltd, 277 p.

Environmental Sampling Technologies, 2008, Product-Semipermeable Membrane Device (SPMD) and its deployment, available online at http://www.est-lab.com/spmd.php. (Accessed March 28, 2008.)

Galloway, J.M., Haggard, B.E., Meyer, M.T., and Green, W.R., 2004, Occurrence of pharmaceuticals and other organic wastewater constituents in selected streams in northern Arkansas, 2004: U.S. Geological Survey Scientific Investigations Report 2005-5140, 24 p. (Also available online at http://pubs.usgs.gov/sir/2005/5140/SIR2005-5140.pdf.)

Gilliom, Robert J., and others, 2006, The quality of our Nation's waters-Pesticides in the Nation's streams and 
ground water, 1992-2001: U.S. Geological Survey Circular 1291, 173 p. (Also available online at http://pubs.usgs.gov/ circ/2005/1291/.)

Huckins, J.N., Petty, J.D., and Booij, Kees, 2006, Monitors of organic chemicals in the environment-Semipermeable Membrane Devices: New York, Springer Science+Business Media, $223 \mathrm{p}$.

Kegley, S.E., Hill, B.R., Orme, S., and Choi, A.H., 2008, PAN Pesticide Database, Pesticide Action Network, North America, available online at http:www.pesticideinfo.org. (Accessed September 9, 2009.)

Kolpin, D.W., Furlong, E.T., Meyer, M.T., Thurman, E.M., Zaugg, S.D., Barber, L.B, and Buxton, H.T., 2002, Pharmaceuticals, hormones, and other organic wastewater contaminants in U.S. streams, 1999-2000-A national reconnaissance: Environmental Science and Technology v. 36 , no. 6 , p. 1,202-1,211.

Kolpin, D.W., Sneck-Fahrer, D.A., Hallberg, G.R., and Libra, R.D., 1997, Temporal trends of selected agricultural chemicals in Iowa's groundwater, 1982-95-Are things getting better?: Journal of Environmental Quality, v. 26, no. 4, p. $1,007-1,017$.

Masoner, J.R., and Mashburn, S.L., 2004, Water quality and possible sources of nitrate in the Cimarron Terrace aquifer, Oklahoma, 2003: U.S. Geological Survey Scientific Investigations Report 2004-5221, 60 p.

Noriega, M.C., Wydoski, D.S., and Foreman, W.T., 2004, Methods of analysis by the U.S. Geological Survey National Water Quality Laboratory-Determination of organochlorine pesticides and polychlorinated biphenyls in bottom and suspended sediment by gas chromatography with electroncapture detection: U.S. Geological Survey Water-Resources Investigations Report 03-4293, 46 p. (Also available online at http://nwql.usgs.gov/Public/pubs/WRIR03-4293/WRIR034293.pdf.)

Oklahoma Department of Environmental Quality, 2009, GIS data viewer, NPDES Outfalls, data collected online at $h t t p: / /$ maps.scigis.com/deq_wq/. (Accessed September 9, 2008.)

Rhomberg, Lorenz, and Seeley, Mara, 2005, Environmental hormone disruptors: Encyclopedia of Toxicology ( $2 \mathrm{~d}$ ed.), Elsevier, Inc., p. 205-208.

Tertuliani, J.S., Alvarez, D.A., Furlong, E.T., Meyer, M.T., Zaugg, S.D., and Koltun, G.F., 2008, Occurrence of organic wastewater compounds in the Tinkers Creek watershed and two other tributaries to the Cuyahoga River, northeast Ohio: U.S. Geological Survey Scientific Investigations Report 2008-5173, $60 \mathrm{p}$.

Tulane and Xavier Universities, Center for Bioenvironmental Research, 2009a, Endocrine disrupting chemicals-Altered states, available online at http://e.hormone.tulane.edu/ learning/endocrine-disrupting-chemicals.html. (Accessed August 29, 2009.)

Tulane and Xavier Universities, Center for Bioenvironmental Research, 2009b, Endocrine disrupting chemicals-Human effects, available online at http://e.hormone.tulane.edu/ learning/human-effects.html. (Accessed August 29, 2009.)

U.S. Department of Labor, Occupational Safety and Health Administration, 2009, Chemical sampling information, available online at $h t t p: / / w w w . o s h a . g o v / d t s /$ chemicalsampling/toc/toc_chemsamp.html. (Accessed September 9, 2008.)

U.S. Environmental Protection Agency, 1995, Public health statement for polycyclic aromatic hydrocarbons (PAHs), available on line at, http://www.atsdr.cdc.gov/toxprofiles/ phs69.html. (Accessed December 22, 2009.)

U.S. Environmental Protection Agency, 2001, National Land Cover Data-Multi-Resolution Land Characteristics Consortium, available online at http://www.epa.gov/mrlc/ nlcd-2001.html. (Accessed September 9, 2008.)

U.S. Environmental Protection Agency, 2002a, Peer consultation workshop on approaches to polycyclic aromatic hydrocarbon (PAH) health assessment: National Center for Environmental Assessment, U.S. Environmental Protection Agency, EPA/635/R-02/005, available online at $h t t p: / / c f p u b$. epa.gov/ncea/cfm/recordisplay.cfm?deid=54787. (Accessed January 12, 2009.)

U.S. Environmental Protection Agency, 2002b, Chlorpyrifos facts: EPA 738-F-01-006, available online at $h t t p: / /$ www.epa.gov/pesticides/reregistration/REDs/factsheets/ chlorpyrifos_fs.htm. (Accessed January 12, 2009.)

U.S. Environmental Protection Agency, 2009a, Drinking water contaminants, organic chemicals, available online at $h t t p: / /$ www.epa.gov/safewater/contaminants/index.html\#organic. (Accessed January 12, 2009.)

U.S. Environmental Protection Agency, 2009b, Basic information about polychlorinated biphenyls (PCBs) in drinking water; http://www.epa.gov/safewater/contaminants/ basicinformation/polychlorinated-biphenyls.html. (Accessed January 4, 2010.)

U.S. Geological Survey, Columbia Environmental Research Center, 2004, Polar Organic Chemical Integrative Sampler (POCIS), available on online at $h t t p: / / w w w . c e r c . u s g s . g o v /$ pubs/center/pdfDSOCs/POCIS.pdf. (Accessed March 12, 2009.)

U.S. Geological Survey, Columbia Environmental Research Center, 2006, Estimated water concentration calculator from SPMD data using PRCs, SPMD calculator version 5, updated November 15, 2006, available online at $h t t p: / / w w w$. 
cerc.usgs.gov/Branches.aspx?BranchId=8. (Accessed January $12,2009$.

Zaugg, S.D., Burkhardt, M.R., Burbank, T.L., Olson, M.C., Iverson, J.L., and Schroeder, M.P., 2006, Determination of semivolatile organic compounds and polycyclic aromatic hydrocarbons in solids by gas chromatography/mass spectrometry, Method ID: O-5506-06: U.S. Geological Survey Techniques and Methods, book 5, chap. B3, 44 p. (Also available online at http://pubs.usgs.gov/tm/2006/tm5b3/.)

Zaugg, S.D., Sandstrom, M.W., Smith, S.G., and Fehlberg, K.M., 1995, Methods of analysis by the U.S. Geological Survey National Water Quality Laboratory-Determination of pesticides in water by $\mathrm{C}-18$ solid-phase extraction and capillary-column gas chromatography/mass spectrometry with selected-ion monitoring, Method ID: O-1126-95: U.S. Geological Survey Open-File Report 95-181, 49 p. (Also available online at http://nwql.usgs.gov/Public/pubs/ OFR95_181.pdf.)

Zaugg, S.D., Smith, S.G., Schroeder, M.P., Barber, L.B., and Burkhardt, M.R., 2007, Methods of analysis by the U.S. Geological Survey National Water Quality LaboratoryDetermination of wastewater compounds by polystyrenedivinylbenzene solid-phase extraction and capillary-column gas chromatography/mass spectrometry: U.S. Geological Survey Water-Resources Investigations Report 01-4186, 37 p. [revised]. 

Appendix 1-Organic Compounds 

Appendix 1. Organic compounds as analyzed in extracts from Semipermeable Membrane Devices or Polar Organic Chemical Integrative Samplers for this study, including suspected endocrine disruption potential, Chemical Abstract Service number, possible compound uses or sources (modified from Zaugg and others [2007] and Tertuliani and others [2008]), sampler type used to sequester compound, and laboratory method used for analysis.

[EDC, known or suspected endocrine disruptor; -, no or status is not known; na, not available; CAS, Chemical Abstract Service; PAH, polycyclic aromatic hydrocarbon; US EPA, U.S. Environmental Protection Agency; SPMD, Semipermeable Membrane Device; Polar Organic Chemical Integrative Sampler, POCIS]




Appendix 1. Organic compounds as analyzed in extracts from Semipermeable Membrane Devices or Polar Organic Chemical Integrative Samplers for this study, including suspected endocrine disruption potential, Chemical Abstract Service number, possible compound uses or sources (modified from Zaugg and others [2007] and Tertuliani and others [2008]), sampler type used to sequester compound, and laboratory method used for analysis. - Continued

[EDC, known or suspected endocrine disruptor; -, no or status is not known; na, not available; CAS, Chemical Abstract Service; PAH, polycyclic aromatic hydrocarbon; US EPA, U.S. Environmental Protection Agency; SPMD, Semipermeable Membrane Device; Polar Organic Chemical Integrative Sampler, POCIS]

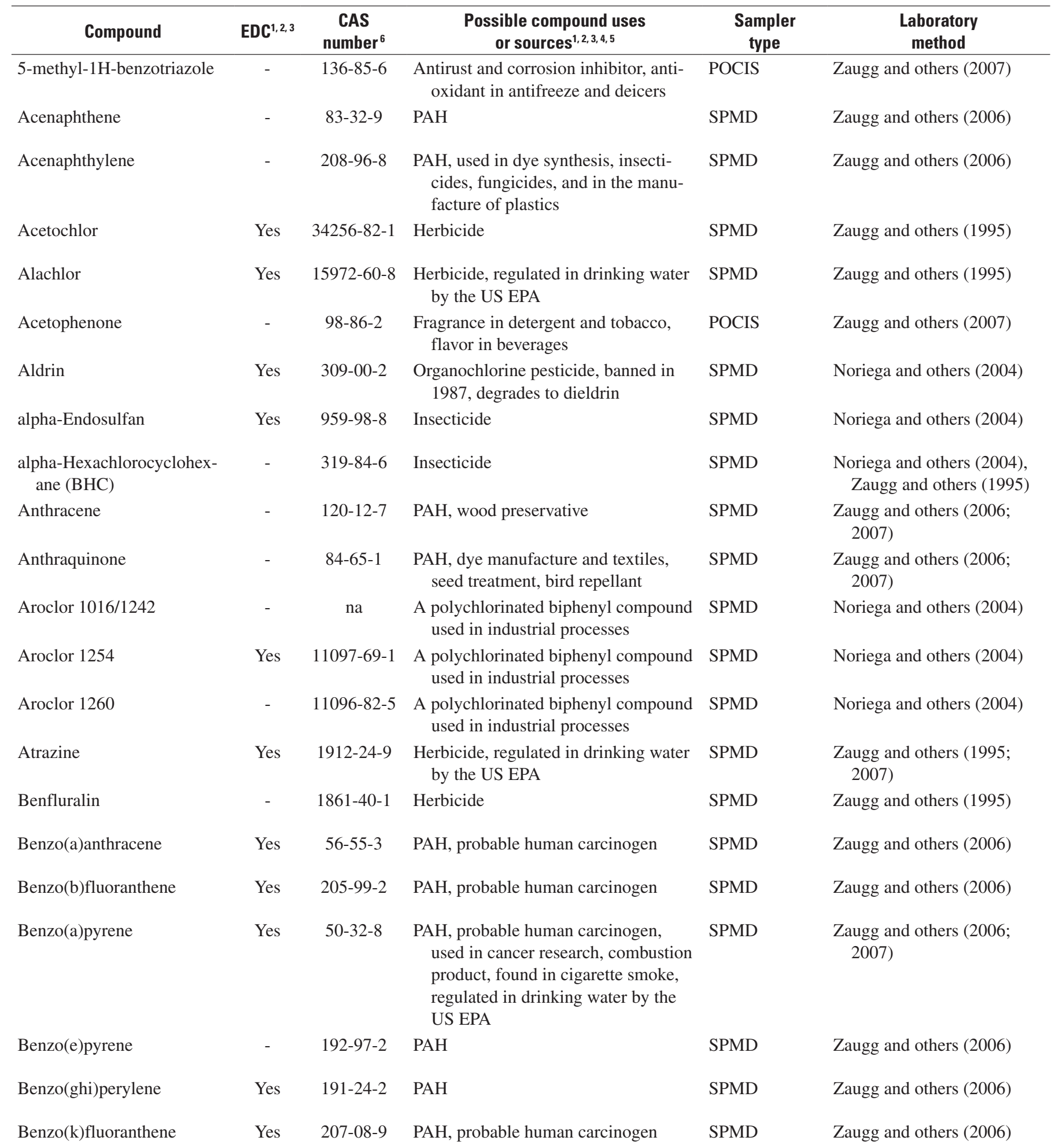


Appendix 1. Organic compounds as analyzed in extracts from Semipermeable Membrane Devices or Polar Organic Chemical Integrative Samplers for this study, including suspected endocrine disruption potential, Chemical Abstract Service number, possible compound uses or sources (modified from Zaugg and others [2007] and Tertuliani and others [2008]), sampler type used to sequester compound, and laboratory method used for analysis.-Continued

[EDC, known or suspected endocrine disruptor; -, no or status is not known; na, not available; CAS, Chemical Abstract Service; PAH, polycyclic aromatic hydrocarbon; US EPA, U.S. Environmental Protection Agency; SPMD, Semipermeable Membrane Device; Polar Organic Chemical Integrative Sampler, POCIS]

\begin{tabular}{|c|c|c|c|c|c|}
\hline Compound & $\mathrm{EDC}^{1,2,3}$ & $\begin{array}{c}\text { CAS } \\
\text { number }^{6}\end{array}$ & $\begin{array}{c}\text { Possible compound uses } \\
\text { or sources }\end{array}$ & $\begin{array}{c}\text { Sampler } \\
\text { type }\end{array}$ & $\begin{array}{c}\text { Laboratory } \\
\text { method }\end{array}$ \\
\hline Benzophenone & Yes & $119-61-9$ & $\begin{array}{l}\text { Ultra violet blocker in perfumes, } \\
\text { soaps, and plastics }\end{array}$ & POCIS & Zaugg and others (2007) \\
\hline beta-Hexachlorobenzene & Yes & $319-85-7$ & Insecticide & SPMD & Noriega and others (2004) \\
\hline beta-Sitosterol & - & $83-46-5$ & Plant sterol & POCIS & Zaugg and others (2007) \\
\hline beta-Stigmastanol & - & $19466-47-8$ & Plant sterol & POCIS & Zaugg and others (2007) \\
\hline Bisphenol A & Yes & $80-05-7$ & $\begin{array}{l}\text { Plasticizer, manufacture of polycar- } \\
\text { bonate resins, antioxidant, fire } \\
\text { repellant }\end{array}$ & POCIS & Zaugg and others (2007) \\
\hline Bromacil & - & $314-40-9$ & General use herbicide & POCIS & Zaugg and others (2007) \\
\hline Bromoform & - & $75-25-2$ & $\begin{array}{l}\text { Wastewater ozonation byproduct, } \\
\text { military/explosives }\end{array}$ & POCIS & Zaugg and others (2007) \\
\hline Butylate & - & $2008-41-5$ & Herbicide & SPMD & Zaugg and others (1995) \\
\hline Caffeine & - & $58-08-2$ & $\begin{array}{l}\text { Beverages, diuretic, very mobile and } \\
\text { biodegradable }\end{array}$ & POCIS & Zaugg and others (2007) \\
\hline Camphor & - & $76-22-2$ & Flavor, odorant, ointments & POCIS & Zaugg and others (2007) \\
\hline Carbaryl & Yes & $63-25-2$ & $\begin{array}{l}\text { Insecticide, crop and garden uses, low } \\
\text { persistence }\end{array}$ & SPMD & $\begin{array}{l}\text { Zaugg and others (1995; } \\
\text { 2007) }\end{array}$ \\
\hline Carbazole & - & $86-74-8$ & $\begin{array}{l}\text { PAH, insecticide, manufacture of dyes, } \\
\text { explosives, and lubricants }\end{array}$ & SPMD & Zaugg and others (2006) \\
\hline Carbofuran & Yes & $1563-66-2$ & Insecticide & SPMD & Zaugg and others (1995) \\
\hline cis-Chlordane & Yes & $5103-71-9$ & $\begin{array}{l}\text { Chlordane metabolite, banned, consid- } \\
\text { ered a legacy pesticide }\end{array}$ & SPMD & Noriega and others (2004) \\
\hline trans-Chlordane & Yes & $5103-74-2$ & $\begin{array}{l}\text { Chlordane metabolite, banned, consid- } \\
\text { ered a legacy pesticide }\end{array}$ & SPMD & Noriega and others (2004) \\
\hline Chlorpyrifos & Yes & $2921-88-2$ & $\begin{array}{l}\text { Insecticide, residential use restricted as } \\
\text { of } 2001 \text {, common name is dursban }\end{array}$ & SPMD, POCIS & $\begin{array}{l}\text { Zaugg and others (1995; } \\
\text { 2007) }\end{array}$ \\
\hline Cholesterol & - & $57-88-5$ & $\begin{array}{l}\text { Often a fecal indicator, also a plant } \\
\text { sterol }\end{array}$ & POCIS & Zaugg and others (2007) \\
\hline Chrysene & Yes & 218-01-9 & PAH, probable human carcinogen & SPMD & Zaugg and others (2006) \\
\hline Cotinine & - & $486-56-6$ & Metabolite of nicotine & POCIS & Zaugg and others (2007) \\
\hline Cumene (Isopropylbenzene) & - & $98-82-8$ & $\begin{array}{l}\text { Manufacture phenol/acetone, fuels and } \\
\text { paint thinner }\end{array}$ & POCIS & Zaugg and others (2007) \\
\hline Cyanazine & Yes & $21725-46-2$ & Herbicide & SPMD & Zaugg and others (1995) \\
\hline Dacthal & - & $1861-32-1$ & Pre-emergent herbicide & SPMD & Zaugg and others (1995) \\
\hline Deethylatrazine & - & $6190-65-4$ & Metabolite of atrazine & SPMD & Zaugg and others (1995) \\
\hline Desulfinylfipronil & - & na & Metabolite of fipronil & SPMD & Zaugg and others (1995) \\
\hline
\end{tabular}




\section{A Reconnaissance of Selected Organic Compounds in Streams in Tribal Lands in Central Oklahoma}

Appendix 1. Organic compounds as analyzed in extracts from Semipermeable Membrane Devices or Polar Organic Chemical Integrative Samplers for this study, including suspected endocrine disruption potential, Chemical Abstract Service number, possible compound uses or sources (modified from Zaugg and others [2007] and Tertuliani and others [2008]), sampler type used to sequester compound, and laboratory method used for analysis.-Continued

[EDC, known or suspected endocrine disruptor; -, no or status is not known; na, not available; CAS, Chemical Abstract Service; PAH, polycyclic aromatic

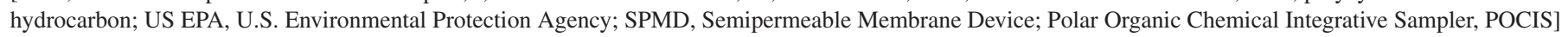

\begin{tabular}{|c|c|c|c|c|c|}
\hline Compound & $\mathrm{EDC}^{1,2,3}$ & $\begin{array}{c}\text { CAS } \\
\text { number }^{6}\end{array}$ & $\begin{array}{l}\text { Possible compound uses } \\
\text { or sources } \\
1,2,3,4,5\end{array}$ & $\begin{array}{l}\text { Sampler } \\
\text { type }\end{array}$ & $\begin{array}{l}\text { Laboratory } \\
\text { method }\end{array}$ \\
\hline Desulfinylfipronil amide & - & na & Metabolite of fipronil & SPMD & Zaugg and others (1995) \\
\hline Dibenz(ah)anthracene & Yes & $53-70-3$ & PAH, probable human carcinogen & SPMD & Zaugg and others (2006) \\
\hline Dieldrin & Yes & $60-57-1$ & $\begin{array}{l}\text { Insecticide, banned in } 1987, \text { consid- } \\
\text { ered a legacy pesticide }\end{array}$ & SPMD & $\begin{array}{l}\text { Noriega and others (2004), } \\
\text { Zaugg and others (1995) }\end{array}$ \\
\hline bis(2-ethylhexyl)phthalate & Yes & $117-81-7$ & $\begin{array}{l}\text { Plasticizer for polymers and resins, } \\
\text { inert ingredient in pesticides }\end{array}$ & SPMD & Zaugg and others (2006) \\
\hline d-Limonene & - & $5989-27-5$ & Fragrance, cleaning products & POCIS & Zaugg and others (2007) \\
\hline Endrin & Yes & $72-20-8$ & $\begin{array}{l}\text { Insecticide, banned, considered a } \\
\text { legacy pesticide, regulated in drink- } \\
\text { ing water by the US EPA }\end{array}$ & SPMD & Noriega and others (2004) \\
\hline Eptam (EPTC) & - & $759-94-4$ & Herbicide & SPMD & Zaugg and others (1995) \\
\hline Ethyl citrate & - & $77-93-0$ & $\begin{array}{l}\text { Solvent, used in paints and perfunes, } \\
\text { used to decaffeinate coffee and tea }\end{array}$ & POCIS & Zaugg and others (2007) \\
\hline Ethalfluralin & - & $55283-68-6$ & Herbicide & SPMD & Zaugg and others (1995) \\
\hline Fluoranthene & - & $206-44-0$ & $\begin{array}{l}\text { PAH, component of coal tar and } \\
\text { asphalt, traces in gasoline and diesel } \\
\text { fuel }\end{array}$ & SPMD, POCIS & $\begin{array}{l}\text { Zaugg and others (2006; } \\
\text { 2007) }\end{array}$ \\
\hline Fluorene & - & $86-73-7$ & PAH, occurs in coal tar & SPMD & Zaugg and others (2006) \\
\hline Fonofos & - & $944-22-9$ & Insecticide & SPMD & Zaugg and others (1995) \\
\hline Galaxolide (HHCB) & Yes & $1222-05-5$ & $\begin{array}{l}\text { Musk fragrance, persistent and wide- } \\
\text { spread in ground water, concern for } \\
\text { bioaccumulation and toxicity }\end{array}$ & POCIS & Zaugg and others (2007) \\
\hline Heptachlor & Yes & $76-44-8$ & $\begin{array}{l}\text { Insecticide, banned in 1974, used as a } \\
\text { termaticide under certain circum- } \\
\text { stances }\end{array}$ & SPMD & Noriega and others (2004) \\
\hline Heptachlor epoxide & Yes & $1024-57-3$ & Metabolite of heptachlor & SPMD & Noriega and others (2004) \\
\hline
\end{tabular}


Appendix 1. Organic compounds as analyzed in extracts from Semipermeable Membrane Devices or Polar Organic Chemical Integrative Samplers for this study, including suspected endocrine disruption potential, Chemical Abstract Service number, possible compound uses or sources (modified from Zaugg and others [2007] and Tertuliani and others [2008]), sampler type used to sequester compound, and laboratory method used for analysis. - Continued

[EDC, known or suspected endocrine disruptor; -, no or status is not known; na, not available; CAS, Chemical Abstract Service; PAH, polycyclic aromatic hydrocarbon; US EPA, U.S. Environmental Protection Agency; SPMD, Semipermeable Membrane Device; Polar Organic Chemical Integrative Sampler, POCIS]

\begin{tabular}{|c|c|c|c|c|c|}
\hline Compound & $\mathrm{EDC}^{1,2,3}$ & $\begin{array}{c}\text { CAS } \\
\text { number }^{6}\end{array}$ & $\begin{array}{l}\text { Possible compound uses } \\
\text { or sources } \\
1,2,3,4,5\end{array}$ & $\begin{array}{l}\text { Sampler } \\
\text { type }\end{array}$ & $\begin{array}{l}\text { Laboratory } \\
\text { method }\end{array}$ \\
\hline Hexachlorobenzene & Yes & $118-74-1$ & $\begin{array}{l}\text { Fungicide, carcinogen, banned from } \\
\text { use }\end{array}$ & SPMD & $\begin{array}{l}\text { Noriega and others (2004), } \\
\text { Zaugg and others (2006) }\end{array}$ \\
\hline Indole & - & $120-72-9$ & $\begin{array}{l}\text { Pesticide inert ingredient, fragrance in } \\
\text { coffee, stench in feces }\end{array}$ & POCIS & Zaugg and others (2007) \\
\hline Isophorone & - & $78-59-1$ & $\begin{array}{l}\text { Solvent for lacquer, plastic, oil, silicon, } \\
\text { resin }\end{array}$ & POCIS & Zaugg and others (2007) \\
\hline Isoquinoline & - & $119-65-3$ & Flavors and fragrances & POCIS & Zaugg and others (2007) \\
\hline Lindane & Yes & $58-89-9$ & Insecticide, banned in 2009 & SPMD & $\begin{array}{l}\text { Zaugg and others (1995), } \\
\text { Noriega and others (2004) }\end{array}$ \\
\hline Malathion & Yes & $121-75-5$ & Insecticide & SPMD & Zaugg and others (1995) \\
\hline Menthol & - & $89-78-1$ & $\begin{array}{l}\text { Liniment, cigarettes, cough drops, } \\
\text { mouthwash }\end{array}$ & POCIS & Zaugg and others (2007) \\
\hline Metalaxyl & - & $57837-19-1$ & Fungicide & POCIS & Zaugg and others (2007) \\
\hline Methyl azinphos & - & $86-50-0$ & Insecticide & SPMD & Zaugg and others (1995) \\
\hline Methyl parathion & Yes & $298-00-0$ & Insecticide & SPMD & Zaugg and others (1995) \\
\hline Methyl salicylate & - & $119-36-8$ & $\begin{array}{l}\text { Liniment, food, beverage, ultra violet- } \\
\text { absorbing lotion }\end{array}$ & POCIS & Zaugg and others (2007) \\
\hline Napropamide & - & $15299-99-7$ & Herbicide & SPMD & Zaugg and others (1995) \\
\hline $\begin{array}{l}\text { N,N-diethyl-meta-toluamide } \\
\text { (DEET) }\end{array}$ & - & $134-62-3$ & $\begin{array}{l}\text { Insecticide, urban uses, mosquito } \\
\text { repellent }\end{array}$ & POCIS & Zaugg and others (2007) \\
\hline Naphthalene & - & $91-20-3$ & $\mathrm{PAH}$, fumigant, moth repellent & SPMD & $\begin{array}{l}\text { Zaugg and others (2006; } \\
\text { 2007) }\end{array}$ \\
\hline p-Cresol & - & $106-44-5$ & Wood preservative & POCIS & Zaugg and others (2007) \\
\hline p-Nonylphenol (total) & Yes & $84852-15-3$ & Nonionic detergent metabolite & POCIS & Zaugg and others (2007) \\
\hline$p, p^{\prime}-\mathrm{DDD}$ & Yes & $72-54-8$ & Metabolite of DDT & SPMD & Noriega and others (2004) \\
\hline$p, p^{\prime}$-DDE & Yes & $72-55-9$ & Metabolite of DDT & SPMD & $\begin{array}{l}\text { Noriega and others (2004), } \\
\text { Zaugg and others (1995) }\end{array}$ \\
\hline
\end{tabular}




\section{A Reconnaissance of Selected Organic Compounds in Streams in Tribal Lands in Central Oklahoma}

Appendix 1. Organic compounds as analyzed in extracts from Semipermeable Membrane Devices or Polar Organic Chemical Integrative Samplers for this study, including suspected endocrine disruption potential, Chemical Abstract Service number, possible compound uses or sources (modified from Zaugg and others [2007] and Tertuliani and others [2008]), sampler type used to sequester compound, and laboratory method used for analysis.-Continued

[EDC, known or suspected endocrine disruptor; -, no or status is not known; na, not available; CAS, Chemical Abstract Service; PAH, polycyclic aromatic hydrocarbon; US EPA, U.S. Environmental Protection Agency; SPMD, Semipermeable Membrane Device; Polar Organic Chemical Integrative Sampler, POCIS]

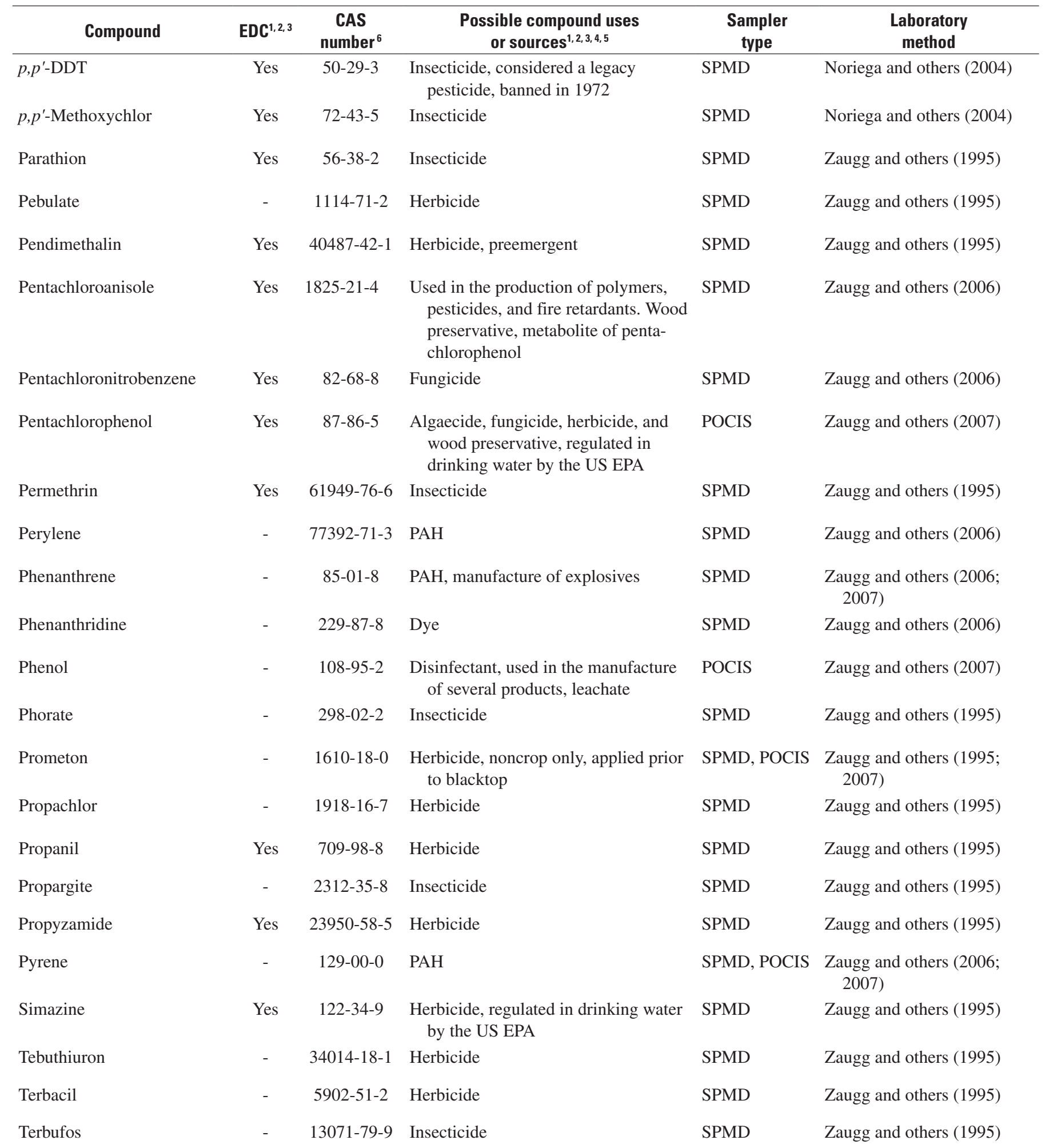


Appendix 1. Organic compounds as analyzed in extracts from Semipermeable Membrane Devices or Polar Organic Chemical Integrative Samplers for this study, including suspected endocrine disruption potential, Chemical Abstract Service number, possible compound uses or sources (modified from Zaugg and others [2007] and Tertuliani and others [2008]), sampler type used to sequester compound, and laboratory method used for analysis. - Continued

[EDC, known or suspected endocrine disruptor; -, no or status is not known; na, not available; CAS, Chemical Abstract Service; PAH, polycyclic aromatic hydrocarbon; US EPA, U.S. Environmental Protection Agency; SPMD, Semipermeable Membrane Device; Polar Organic Chemical Integrative Sampler, POCIS]

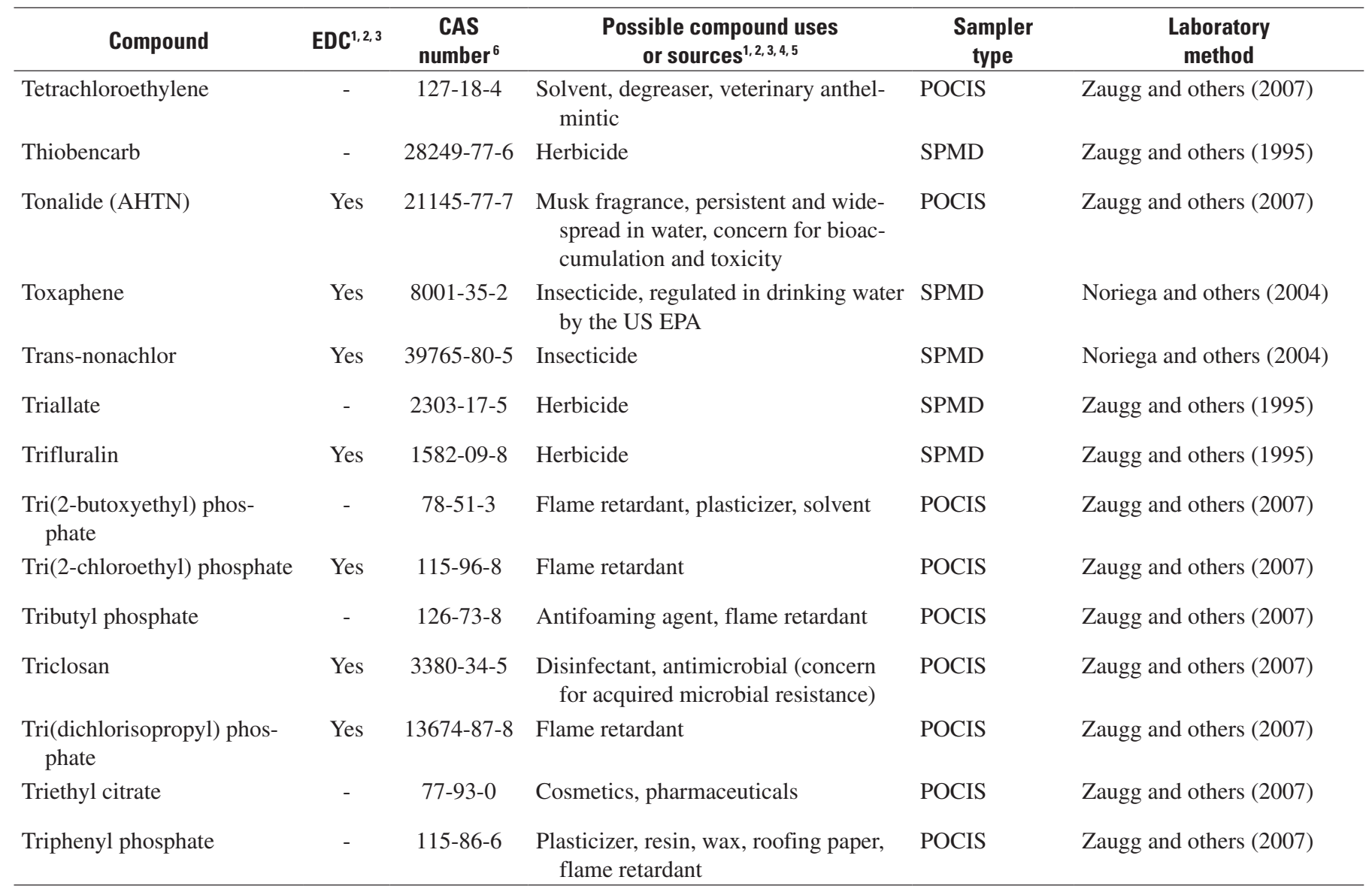

\footnotetext{
${ }^{1}$ Kegley and others (2008).
}

${ }^{2}$ U.S. Department of Labor, Occupational Safety and Health Administration (2009).

${ }^{3}$ U.S. Environmental Protection Agency (1995).

${ }^{4}$ U.S. Environmental Protection Agency (2002b).

${ }^{5}$ U.S. Environmental Protection Agency (2009b).

${ }^{6}$ This report contains CAS Registry Numbers ${ }^{\circledR}$, which is a Registered Trademark of the American Chemical Society. CAS recommends the verification of the CASRNs through CAS Client Services ${ }^{\mathrm{SM}}$. 



\section{Appendix 2-Concentrations of Pesticides and Pesticide Metabolites}





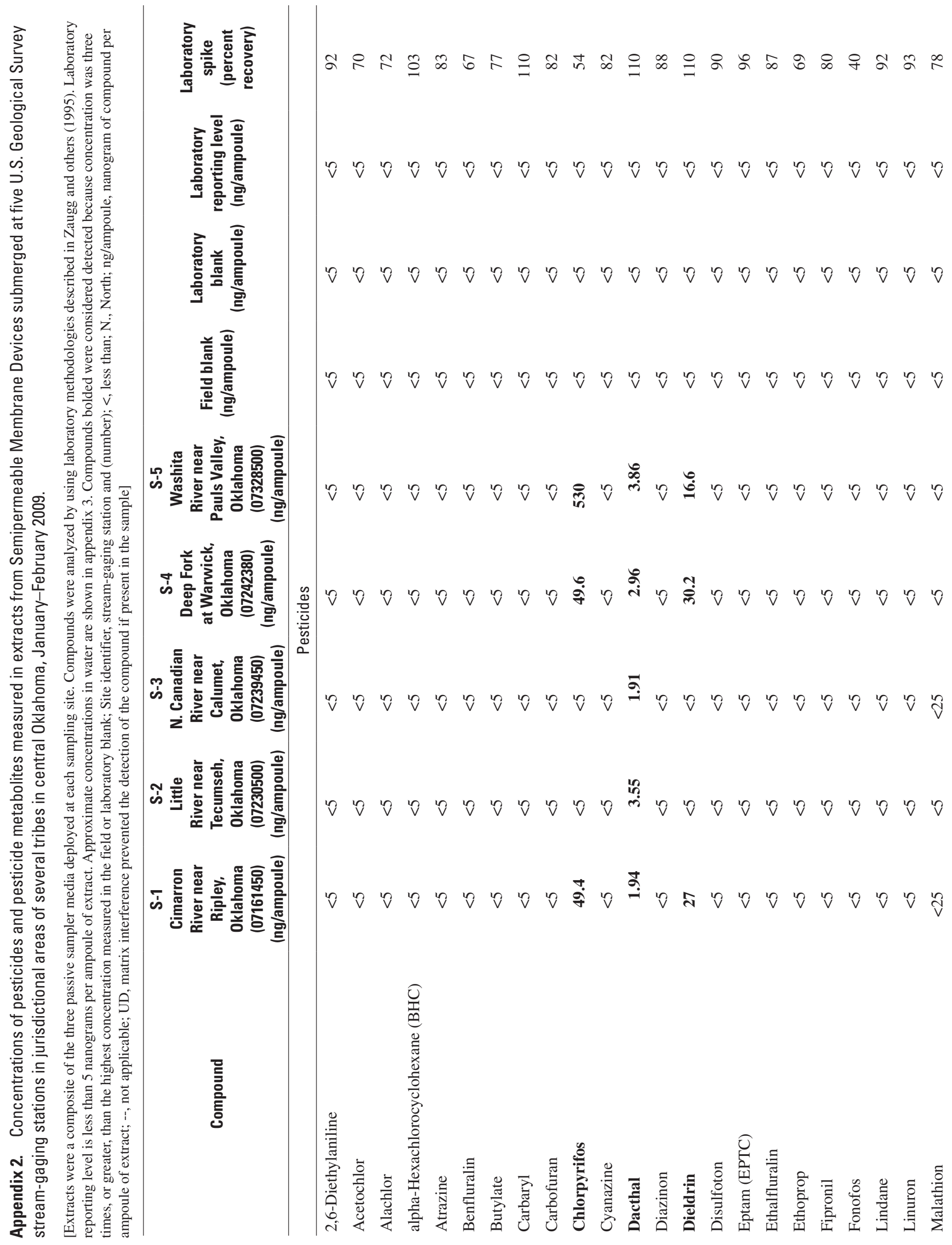




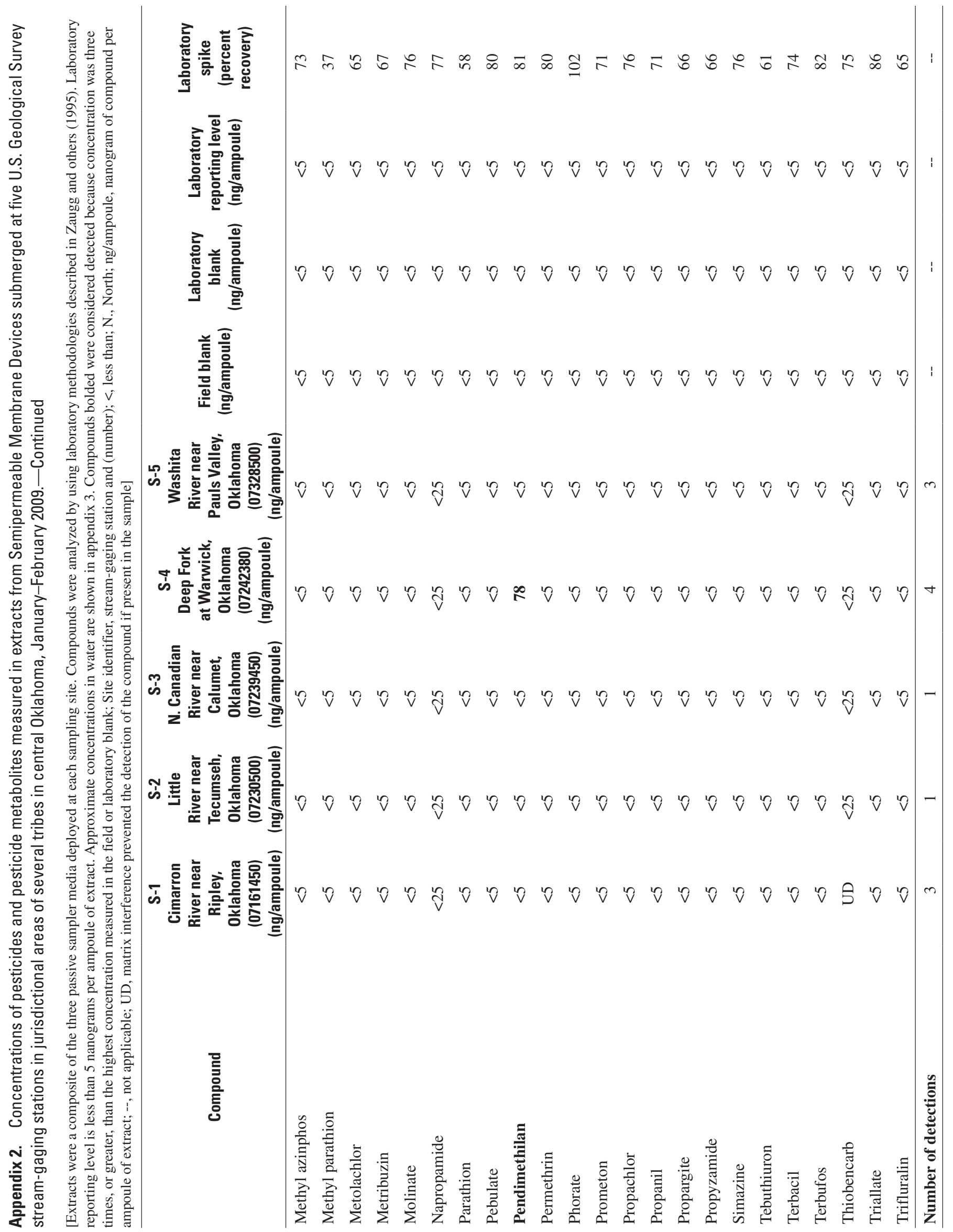




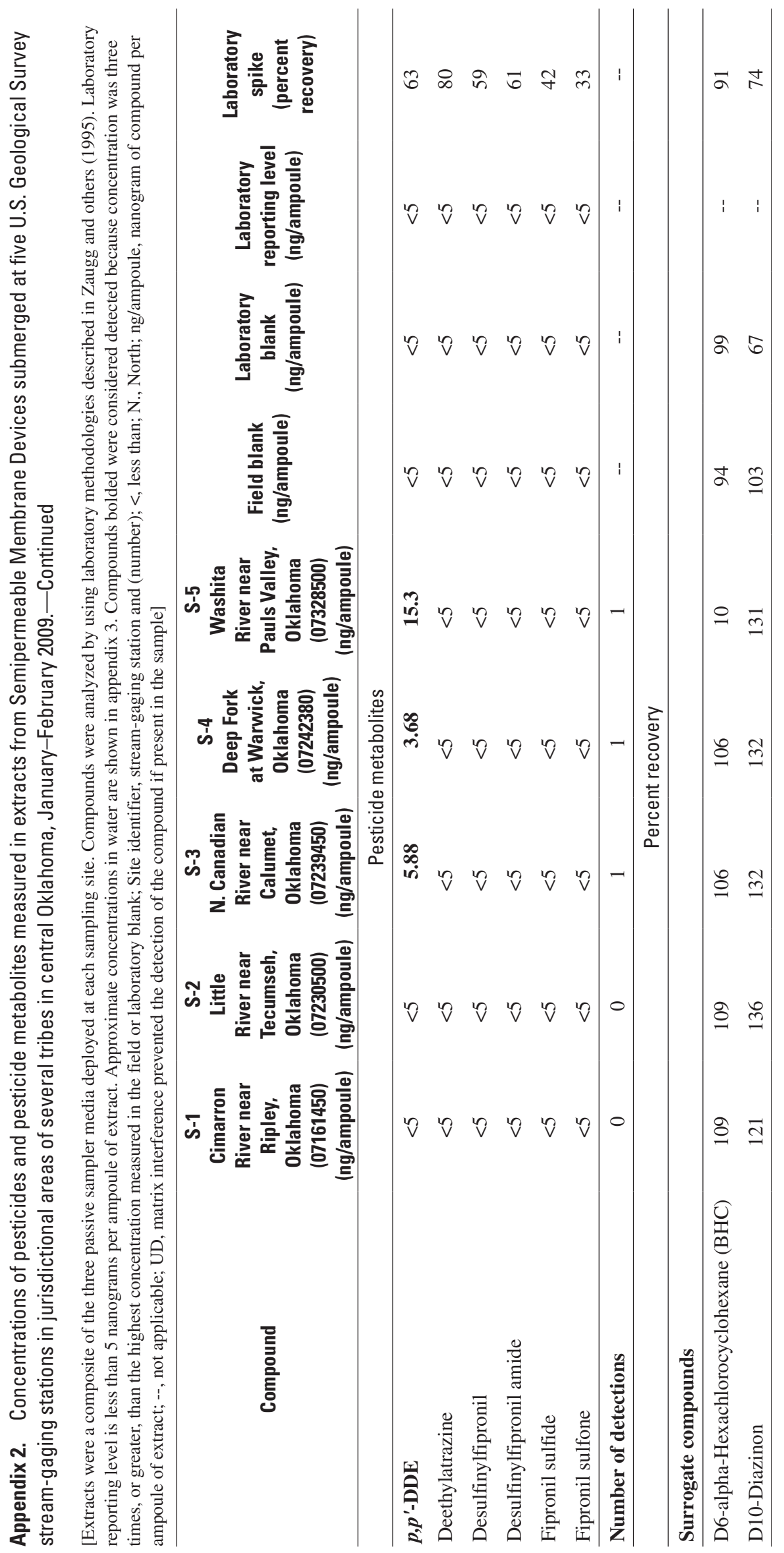





\section{Appendix 3-Approximate Concentrations of Pesticides and Pesticide Metabolites}



Appendix 3. Approximate concentrations of pesticides and pesticide metabolites in water calculated using performance reference compounds measured in extracts from Semipermeable Membrane Devices submerged at five U.S. Geological Survey stream-gaging stations in jurisdictional areas of several tribes in central Oklahoma, January-February 2009.

[Extracts were a composite of three Semipermeable Membrane Device media deployed at each sampling site. Compounds were analyzed by using laboratory methodologies described in Zaugg and others (1995). Compounds that are bolded were considered detected because concentration of the compound measured in the extract was three times, or greater, than the highest concentration measured in the field or laboratory blank. Concentrations measured in extracts are shown in appendix 2. All concentrations are in nanogram of compound per liter of water; N, North; site identifier, stream-gaging station and (number); Nc, not calculated because the concentration measured in the extract was below the laboratory reporting level]

\begin{tabular}{|c|c|c|c|c|c|}
\hline Compound & $\begin{array}{c}\text { S-1 } \\
\text { Cimarron River } \\
\text { near Ripley, } \\
\text { Oklahoma } \\
(07161450) \\
\end{array}$ & $\begin{array}{c}\text { S-2 } \\
\text { Little River near } \\
\text { Tecumseh, } \\
\text { Oklahoma } \\
(07230500) \\
\end{array}$ & $\begin{array}{c}\text { S-3 } \\
\text { N. Canadian River } \\
\text { near Calumet, } \\
\text { Oklahoma } \\
(07239450) \\
\end{array}$ & $\begin{array}{c}\text { S-4 } \\
\text { Deep Fork at } \\
\text { Warwick, } \\
\text { Oklahoma } \\
\text { (07242380) } \\
\end{array}$ & $\begin{array}{c}\text { S-5 } \\
\text { Washita River } \\
\text { near Pauls Valley, } \\
\text { Oklahoma } \\
(07328500) \\
\end{array}$ \\
\hline 2,6-Diethylanaline & $\mathrm{Nc}$ & $\mathrm{Nc}$ & $\mathrm{Nc}$ & $\mathrm{Nc}$ & $\mathrm{Nc}$ \\
\hline Acetochlor & $\mathrm{Nc}$ & $\mathrm{Nc}$ & $\mathrm{Nc}$ & $\mathrm{Nc}$ & $\mathrm{Nc}$ \\
\hline Alachlor & $\mathrm{Nc}$ & $\mathrm{Nc}$ & $\mathrm{Nc}$ & $\mathrm{Nc}$ & $\mathrm{Nc}$ \\
\hline alpha-Hexachlorocyclohexane & $\mathrm{Nc}$ & $\mathrm{Nc}$ & $\mathrm{Nc}$ & $\mathrm{Nc}$ & $\mathrm{Nc}$ \\
\hline Atrazine & $\mathrm{Nc}$ & $\mathrm{Nc}$ & $\mathrm{Nc}$ & $\mathrm{Nc}$ & $\mathrm{Nc}$ \\
\hline Benfluralin & $\mathrm{Nc}$ & $\mathrm{Nc}$ & $\mathrm{Nc}$ & $\mathrm{Nc}$ & $\mathrm{Nc}$ \\
\hline Butylate & $\mathrm{Nc}$ & $\mathrm{Nc}$ & $\mathrm{Nc}$ & $\mathrm{Nc}$ & $\mathrm{Nc}$ \\
\hline Carbaryl & $\mathrm{Nc}$ & $\mathrm{Nc}$ & $\mathrm{Nc}$ & $\mathrm{Nc}$ & $\mathrm{Nc}$ \\
\hline Carbofuran & $\mathrm{Nc}$ & $\mathrm{Nc}$ & $\mathrm{Nc}$ & $\mathrm{Nc}$ & $\mathrm{Nc}$ \\
\hline Chlorpyrifos & 1.41 & $\mathrm{Nc}$ & 1.64 & .18 & 2.74 \\
\hline Cyanazine & $\mathrm{Nc}$ & $\mathrm{Nc}$ & $\mathrm{Nc}$ & $\mathrm{Nc}$ & $\mathrm{Nc}$ \\
\hline Dacthal & .07 & .01 & .01 & .01 & .02 \\
\hline Diazinon & $\mathrm{Nc}$ & $\mathrm{Nc}$ & $\mathrm{Nc}$ & $\mathrm{Nc}$ & $\mathrm{Nc}$ \\
\hline Dieldrin & .72 & $\mathrm{Nc}$ & .07 & .04 & .06 \\
\hline Disulfoton & $\mathrm{Nc}$ & $\mathrm{Nc}$ & $\mathrm{Nc}$ & $\mathrm{Nc}$ & $\mathrm{Nc}$ \\
\hline Eptam (EPTC) & $\mathrm{Nc}$ & $\mathrm{Nc}$ & $\mathrm{Nc}$ & $\mathrm{Nc}$ & $\mathrm{Nc}$ \\
\hline Ethalfluralin & $\mathrm{Nc}$ & $\mathrm{Nc}$ & $\mathrm{Nc}$ & $\mathrm{Nc}$ & $\mathrm{Nc}$ \\
\hline Ethoprop & $\mathrm{Nc}$ & $\mathrm{Nc}$ & $\mathrm{Nc}$ & $\mathrm{Nc}$ & $\mathrm{Nc}$ \\
\hline Fipronil & $\mathrm{Nc}$ & $\mathrm{Nc}$ & $\mathrm{Nc}$ & $\mathrm{Nc}$ & $\mathrm{Nc}$ \\
\hline Fonofos & $\mathrm{Nc}$ & $\mathrm{Nc}$ & $\mathrm{Nc}$ & $\mathrm{Nc}$ & $\mathrm{Nc}$ \\
\hline Lindane & $\mathrm{Nc}$ & $\mathrm{Nc}$ & $\mathrm{Nc}$ & $\mathrm{Nc}$ & $\mathrm{Nc}$ \\
\hline Linuron & $\mathrm{Nc}$ & $\mathrm{Nc}$ & $\mathrm{Nc}$ & $\mathrm{Nc}$ & $\mathrm{Nc}$ \\
\hline Malathion & $\mathrm{Nc}$ & $\mathrm{Nc}$ & $\mathrm{Nc}$ & $\mathrm{Nc}$ & $\mathrm{Nc}$ \\
\hline Methyl azinphos & $\mathrm{Nc}$ & $\mathrm{Nc}$ & $\mathrm{Nc}$ & $\mathrm{Nc}$ & $\mathrm{Nc}$ \\
\hline Methyl parathion & $\mathrm{Nc}$ & $\mathrm{Nc}$ & $\mathrm{Nc}$ & $\mathrm{Nc}$ & $\mathrm{Nc}$ \\
\hline Metolachlor & $\mathrm{Nc}$ & $\mathrm{Nc}$ & $\mathrm{Nc}$ & $\mathrm{Nc}$ & $\mathrm{Nc}$ \\
\hline Metribuzin & $\mathrm{Nc}$ & $\mathrm{Nc}$ & $\mathrm{Nc}$ & $\mathrm{Nc}$ & $\mathrm{Nc}$ \\
\hline Molinate & $\mathrm{Nc}$ & $\mathrm{Nc}$ & $\mathrm{Nc}$ & $\mathrm{Nc}$ & $\mathrm{Nc}$ \\
\hline Napropamide & $\mathrm{Nc}$ & $\mathrm{Nc}$ & $\mathrm{Nc}$ & $\mathrm{Nc}$ & $\mathrm{Nc}$ \\
\hline Parathion & $\mathrm{Nc}$ & $\mathrm{Nc}$ & $\mathrm{Nc}$ & $\mathrm{Nc}$ & $\mathrm{Nc}$ \\
\hline Pebulate & $\mathrm{Nc}$ & $\mathrm{Nc}$ & $\mathrm{Nc}$ & $\mathrm{Nc}$ & $\mathrm{Nc}$ \\
\hline Pendimethilan & $\mathrm{Nc}$ & $\mathrm{Nc}$ & $\mathrm{Nc}$ & .15 & $\mathrm{Nc}$ \\
\hline Permethrin & $\mathrm{Nc}$ & $\mathrm{Nc}$ & $\mathrm{Nc}$ & $\mathrm{Nc}$ & $\mathrm{Nc}$ \\
\hline Phorate & $\mathrm{Nc}$ & $\mathrm{Nc}$ & $\mathrm{Nc}$ & $\mathrm{Nc}$ & $\mathrm{Nc}$ \\
\hline
\end{tabular}


Appendix 3. Approximate concentrations of pesticides and pesticide metabolites in water calculated using performance reference compounds measured in extracts from Semipermeable Membrane Devices submerged at five U.S. Geological Survey stream-gaging stations in jurisdictional areas of several tribes in central Oklahoma, January-February 2009._Continued

[Extracts were a composite of three Semipermeable Membrane Device media deployed at each sampling site. Compounds were analyzed by using laboratory methodologies described in Zaugg and others (1995). Compounds that are bolded were considered detected because concentration of the compound measured in the extract was three times, or greater, than the highest concentration measured in the field or laboratory blank. Concentrations measured in extracts are shown in appendix 2. All concentrations are in nanogram of compound per liter of water; N, North; site identifier, stream-gaging station and (number); Nc, not calculated because the concentration measured in the extract was below the laboratory reporting level]

\begin{tabular}{|c|c|c|c|c|c|}
\hline Compound & $\begin{array}{c}\text { S-1 } \\
\text { Cimarron River } \\
\text { near Ripley, } \\
\text { Oklahoma } \\
(07161450) \\
\end{array}$ & $\begin{array}{c}\text { S-2 } \\
\text { Little River near } \\
\text { Tecumseh, } \\
\text { Oklahoma } \\
\text { (07230500) } \\
\end{array}$ & $\begin{array}{c}\text { S-3 } \\
\text { N. Canadian River } \\
\text { near Calumet, } \\
\text { Oklahoma } \\
(07239450) \\
\end{array}$ & $\begin{array}{c}\text { S-4 } \\
\text { Deep Fork at } \\
\text { Warwick, } \\
\text { Oklahoma } \\
\text { (07242380) } \\
\end{array}$ & $\begin{array}{c}\text { S-5 } \\
\text { Washita River } \\
\text { near Pauls Valley, } \\
\text { Oklahoma } \\
(07328500) \\
\end{array}$ \\
\hline Prometon & $\mathrm{Nc}$ & $\mathrm{Nc}$ & $\mathrm{Nc}$ & $\mathrm{Nc}$ & $\mathrm{Nc}$ \\
\hline Propachlor & $\mathrm{Nc}$ & $\mathrm{Nc}$ & $\mathrm{Nc}$ & $\mathrm{Nc}$ & $\mathrm{Nc}$ \\
\hline Propanil & $\mathrm{Nc}$ & $\mathrm{Nc}$ & $\mathrm{Nc}$ & $\mathrm{Nc}$ & $\mathrm{Nc}$ \\
\hline Propargite & $\mathrm{Nc}$ & $\mathrm{Nc}$ & $\mathrm{Nc}$ & $\mathrm{Nc}$ & $\mathrm{Nc}$ \\
\hline Propyzamide & $\mathrm{Nc}$ & $\mathrm{Nc}$ & $\mathrm{Nc}$ & $\mathrm{Nc}$ & $\mathrm{Nc}$ \\
\hline Simazine & $\mathrm{Nc}$ & $\mathrm{Nc}$ & $\mathrm{Nc}$ & $\mathrm{Nc}$ & $\mathrm{Nc}$ \\
\hline Tebuthiuron & $\mathrm{Nc}$ & $\mathrm{Nc}$ & $\mathrm{Nc}$ & $\mathrm{Nc}$ & $\mathrm{Nc}$ \\
\hline Terbacil & $\mathrm{Nc}$ & $\mathrm{Nc}$ & $\mathrm{Nc}$ & $\mathrm{Nc}$ & $\mathrm{Nc}$ \\
\hline Terbufos & $\mathrm{Nc}$ & $\mathrm{Nc}$ & $\mathrm{Nc}$ & $\mathrm{Nc}$ & $\mathrm{Nc}$ \\
\hline Thiobencarb & $\mathrm{Nc}$ & $\mathrm{Nc}$ & $\mathrm{Nc}$ & $\mathrm{Nc}$ & $\mathrm{Nc}$ \\
\hline Triallate & $\mathrm{Nc}$ & $\mathrm{Nc}$ & $\mathrm{Nc}$ & $\mathrm{Nc}$ & $\mathrm{Nc}$ \\
\hline Trifluralin & $\mathrm{Nc}$ & $\mathrm{Nc}$ & $\mathrm{Nc}$ & $\mathrm{Nc}$ & $\mathrm{Nc}$ \\
\hline \multicolumn{6}{|c|}{ Pesticide metabolites } \\
\hline$p, p^{\prime}-\mathrm{DDE}$ & $\mathrm{Nc}$ & $\mathrm{Nc}$ & .03 & .01 & .06 \\
\hline Deethylatrazine & $\mathrm{Nc}$ & $\mathrm{Nc}$ & $\mathrm{Nc}$ & $\mathrm{Nc}$ & $\mathrm{Nc}$ \\
\hline Desulfinyl fipronil & $\mathrm{Nc}$ & $\mathrm{Nc}$ & $\mathrm{Nc}$ & $\mathrm{Nc}$ & $\mathrm{Nc}$ \\
\hline Desulfinyl fipronil amide & $\mathrm{Nc}$ & $\mathrm{Nc}$ & $\mathrm{Nc}$ & $\mathrm{Nc}$ & $\mathrm{Nc}$ \\
\hline Fipronil sulfide & $\mathrm{Nc}$ & $\mathrm{Nc}$ & $\mathrm{Nc}$ & $\mathrm{Nc}$ & $\mathrm{Nc}$ \\
\hline Fipronil sulfone & $\mathrm{Nc}$ & $\mathrm{Nc}$ & $\mathrm{Nc}$ & $\mathrm{Nc}$ & $\mathrm{Nc}$ \\
\hline
\end{tabular}



Appendix 4-Concentrations of Pesticides, Pesticide Metabolites, Polychlorinated Biphenyl Compounds, Polycyclic Aromatic Hydrocarbons, and Other Types of Synthetic Organic Compounds 

Appendix 4. Concentrations of pesticides, pesticide metabolites, polychlorinated biphenyl compounds, polycyclic aromatic hydrocarbons, and other types of synthetic organic compounds measured in extracts from Semipermeable Membrane Devices or Polar Organic Chemical Integrative Samplers submerged at two stream sites on the North Canadian River adjacent to the Kickapoo tribal lands in central Oklahoma, January-February 2009.

[Compound concentrations measured in extracts are reported in nanogram per ampoule of extract from a composite of three SPMD or three POCIS media in each sampler. Compounds that are bolded were considered detected because concentration was three times, or greater, than the highest concentration measured in the field or laboratory blank. A compound measured by more than one laboratory method was counted only once as a detection; site identifier, stream-gaging station and (number); N., north; ng/L, nanogram of compound per liter of water; ng/ampoule, nanogram of compound per ampoule of extract; <, less than; E, concentration is approximate because trace levels of contamination were found in the blanks at levels below the reporting level; R-Delete, spike fraction was lost during sample preparation at laboratory; --, not applicable; *, indicates compound could not be positively identified in the extract below the reported concentration because of chromatographic interference; $\mathrm{Nc}$, not calculated because presence of the compound could not be positively identified in the extract or concentration was below the laboratory reporting level; UD, compound was not recovered most likely because of residual isopropanol from the addition of spike and surrogate solution; Np, water concentration could not be calculated because compound was measured in extract from Polar Organic Integrative Sampler which did not have performance reference compounds needed for calculation]

\begin{tabular}{|c|c|c|c|c|c|c|c|c|}
\hline \multirow[t]{2}{*}{ Compound } & \multicolumn{2}{|c|}{$\begin{array}{c}\text { PS-1 } \\
\text { N. Canadian River at } \\
\text { Hogback Road near } \\
\text { Jones, Oklahoma } \\
\text { (07241540) }\end{array}$} & \multicolumn{2}{|c|}{$\begin{array}{c}\text { PS-2 } \\
\text { N. Canadian River } \\
\text { near Shawnee, } \\
\text { Oklahoma } \\
(07241700) \\
\end{array}$} & \multirow[t]{2}{*}{$\begin{array}{l}\text { Field blank } \\
\text { (ng/ampoule) }\end{array}$} & \multirow[t]{2}{*}{$\begin{array}{l}\text { Laboratory } \\
\text { blank } \\
\text { (ng/ampoule) }\end{array}$} & \multirow[t]{2}{*}{$\begin{array}{l}\text { Laboratory } \\
\text { reporting } \\
\text { level } \\
\text { (ng/ampoule) }\end{array}$} & \multirow[t]{2}{*}{$\begin{array}{l}\text { Laboratory } \\
\text { spike } \\
\text { (percent } \\
\text { recovery) }\end{array}$} \\
\hline & (ng/ampoule) & (ng/L) & (ng/ampoule) & (ng/L) & & & & \\
\hline \multicolumn{9}{|c|}{ Pesticides } \\
\hline 2,6-Diethylaniline & $<5$ & $\mathrm{Nc}$ & $<5$ & $\mathrm{Nc}$ & $<5$ & $<5$ & $<5$ & 92 \\
\hline Acetochlor & $<5$ & $\mathrm{Nc}$ & $<5$ & $\mathrm{Nc}$ & $<5$ & $<5$ & $<5$ & 70 \\
\hline Alachlor & $<5$ & $\mathrm{Nc}$ & $<5$ & $\mathrm{Nc}$ & $<5$ & $<5$ & $<5$ & 72 \\
\hline Aldrin & $<2.0$ & $\mathrm{Nc}$ & $<2.0$ & $\mathrm{Nc}$ & $<2.0$ & $<2.0$ & $<2.0$ & 92 \\
\hline alpha-Endosulfan & $<.5$ & $\mathrm{Nc}$ & $<.5$ & $\mathrm{Nc}$ & $<.5$ & $<.5$ & $<.5$ & R-Delete \\
\hline $\begin{array}{l}\text { alpha-Hexachlorocyclo- } \\
\text { hexane (BHC) }\end{array}$ & $<1.5$ & $\mathrm{Nc}$ & $<1.5$ & $\mathrm{Nc}$ & $<1.5$ & $<1.5$ & $<1.5$ & R-Delete \\
\hline $\begin{array}{l}\text { alpha-Hexachlorocyclo- } \\
\text { hexane (BHC) }\end{array}$ & $<5$ & $\mathrm{Nc}$ & $<5$ & $\mathrm{Nc}$ & $<5$ & $<5$ & $<5$ & 103 \\
\hline Atrazine & $<5$ & $\mathrm{Nc}$ & $<5$ & $\mathrm{Nc}$ & $<5$ & $<5$ & $<5$ & 83 \\
\hline Atrazine & 200 & $\mathrm{~Np}$ & 200 & $\mathrm{~Np}$ & $<.04$ & $<.04$ & $<.04$ & 100 \\
\hline Benfluralin & $<5$ & $\mathrm{Nc}$ & $<5$ & $\mathrm{Nc}$ & $<5$ & $<5$ & $<5$ & 67 \\
\hline beta-Hexachlorobenzene & $<.5$ & $\mathrm{Nc}$ & $<.5$ & $\mathrm{Nc}$ & $<.5$ & $<.5$ & $<.5$ & R-Delete \\
\hline Bromacil & $<680 *$ & $\mathrm{~Np}$ & $<640^{*}$ & $\mathrm{~Np}$ & $<.08$ & $<.08$ & $<.08$ & 101 \\
\hline Butylate & $<5$ & $\mathrm{Nc}$ & $<5$ & $\mathrm{Nc}$ & $<5$ & $<5$ & $<5$ & 77 \\
\hline Carbaryl & $<180^{*}$ & $\mathrm{~Np}$ & $<250 *$ & $\mathrm{~Np}$ & $<44^{*}$ & $<.03$ & $<.03$ & 97 \\
\hline Carbaryl & $<5$ & $\mathrm{Nc}$ & $<5$ & $\mathrm{Nc}$ & $<5$ & $<5$ & $<5$ & 110 \\
\hline Carbofuran & $<5$ & $\mathrm{Nc}$ & $<5$ & $\mathrm{Nc}$ & $<5$ & $<5$ & $<5$ & 82 \\
\hline Chlorpyrifos & 340 & 1.88 & 370 & 1.85 & $<5$ & $<5$ & $<5$ & 54 \\
\hline Chlorpyrifos & $<.16$ & $\mathrm{~Np}$ & $<.16$ & $\mathrm{~Np}$ & $<.16$ & $<.16$ & $<.16$ & 91 \\
\hline Cyanazine & $<5$ & $\mathrm{Nc}$ & $<5$ & $\mathrm{Nc}$ & $<5$ & $<5$ & $<5$ & 82 \\
\hline Dacthal & 9.02 & .05 & 8.91 & .05 & $<5$ & $<5$ & $<5$ & 110 \\
\hline Diazinon & $<5$ & $\mathrm{Nc}$ & $<5$ & $\mathrm{Nc}$ & $<5$ & $<5$ & $<5$ & 88 \\
\hline Diazinon & $<.16$ & $\mathrm{~Np}$ & $<.16$ & $\mathrm{~Np}$ & $<.16$ & $<.16$ & $<.16$ & 95 \\
\hline Dieldrin & 180 & .84 & 120 & .50 & $<.5$ & $<.5$ & $<.5$ & R-Delete \\
\hline Dieldrin & 300 & 1.09 & 160 & .52 & $<5$ & $<5$ & $<5$ & 110 \\
\hline Disulfoton & $<5$ & $\mathrm{Nc}$ & $<5$ & $\mathrm{Nc}$ & $<5$ & $<5$ & $<5$ & 90 \\
\hline Endrin & $<1.0$ & $\mathrm{Nc}$ & $<1.0$ & $\mathrm{Nc}$ & $<1.0$ & $<1.0$ & $<1.0$ & R-Delete \\
\hline Eptam (EPTC) & $<5$ & $\mathrm{Nc}$ & $<5$ & $\mathrm{Nc}$ & $<5$ & $<5$ & $<5$ & 96 \\
\hline
\end{tabular}


Appendix 4. Concentrations of pesticides, pesticide metabolites, polychlorinated biphenyl compounds, polycyclic aromatic hydrocarbons, and other types of synthetic organic compounds measured in extracts from Semipermeable Membrane Devices or Polar Organic Chemical Integrative Samplers submerged at two stream sites on the North Canadian River adjacent to the Kickapoo tribal lands in central Oklahoma, January-February 2009.-Continued

[Compound concentrations measured in extracts are reported in nanogram per ampoule of extract from a composite of three SPMD or three POCIS media in each sampler. Compounds that are bolded were considered detected because concentration was three times, or greater, than the highest concentration measured in the field or laboratory blank. A compound measured by more than one laboratory method was counted only once as a detection; site identifier, stream-gaging station and (number); N., north; ng/L, nanogram of compound per liter of water; ng/ampoule, nanogram of compound per ampoule of extract; <, less than; E, concentration is approximate because trace levels of contamination were found in the blanks at levels below the reporting level; R-Delete, spike fraction was lost during sample preparation at laboratory; --, not applicable; *, indicates compound could not be positively identified in the extract below the reported concentration because of chromatographic interference; Nc, not calculated because presence of the compound could not be positively identified in the extract or concentration was below the laboratory reporting level; UD, compound was not recovered most likely because of residual isopropanol from the addition of spike and surrogate solution; $\mathrm{Np}$, water concentration could not be calculated because compound was measured in extract from Polar Organic Integrative Sampler which did not have performance reference compounds needed for calculation]

\begin{tabular}{|c|c|c|c|c|c|c|c|c|}
\hline \multirow[t]{2}{*}{ Compound } & \multicolumn{2}{|c|}{$\begin{array}{c}\text { PS-1 } \\
\text { N. Canadian River at } \\
\text { Hogback Road near } \\
\text { Jones, Oklahoma } \\
\text { (07241540) }\end{array}$} & \multicolumn{2}{|c|}{$\begin{array}{c}\text { PS-2 } \\
\text { N. Canadian River } \\
\text { near Shawnee, } \\
\text { Oklahoma } \\
\text { (07241700) }\end{array}$} & \multirow[t]{2}{*}{$\begin{array}{c}\text { Field blank } \\
\text { (ng/ampoule) }\end{array}$} & \multirow[t]{2}{*}{$\begin{array}{l}\text { Laboratory } \\
\text { blank } \\
\text { (ng/ampoule) }\end{array}$} & \multirow[t]{2}{*}{$\begin{array}{l}\text { Laboratory } \\
\text { reporting } \\
\text { level } \\
\text { (ng/ampoule) }\end{array}$} & \multirow[t]{2}{*}{$\begin{array}{l}\text { Laboratory } \\
\text { spike } \\
\text { (percent } \\
\text { recovery) }\end{array}$} \\
\hline & (ng/ampoule) & (ng/L) & (ng/ampoule) & (ng/L) & & & & \\
\hline Ethalfluralin & $<5$ & $\mathrm{Nc}$ & $<5$ & $\mathrm{Nc}$ & $<5$ & $<5$ & $<5$ & 87 \\
\hline Ethoprop & $<5$ & $\mathrm{Nc}$ & $<5$ & $\mathrm{Nc}$ & $<5$ & $<5$ & $<5$ & 69 \\
\hline Fipronil & $<5$ & $\mathrm{Nc}$ & $<5$ & $\mathrm{Nc}$ & $<5$ & $<5$ & $<5$ & 80 \\
\hline Fonofos & $<5$ & $\mathrm{Nc}$ & $<5$ & $\mathrm{Nc}$ & $<5$ & $<5$ & $<5$ & 40 \\
\hline Heptachlor & 27.5 & .10 & $<1.0$ & $\mathrm{Nc}$ & $<1.0$ & $<1.0$ & $<1.0$ & 86 \\
\hline Hexachlorobenzene & $<3.0$ & $\mathrm{Nc}$ & $<3.0$ & $\mathrm{Nc}$ & $<3.0$ & $<3.0$ & $<3.0$ & 84 \\
\hline Hexachlorobenzene & $<75^{*}$ & $\mathrm{Nc}$ & $<70^{*}$ & $\mathrm{Nc}$ & $<25$ & $<25$ & $<25$ & 110 \\
\hline Lindane & $<5$ & $\mathrm{Nc}$ & $<5$ & $\mathrm{Nc}$ & $<5$ & $<5$ & $<5$ & 92 \\
\hline Lindane & $<.5$ & $\mathrm{Nc}$ & $<.5$ & $\mathrm{Nc}$ & $<.5$ & $<.5$ & $<.5$ & R-Delete \\
\hline Linuron & $<5$ & $\mathrm{Nc}$ & $<5$ & $\mathrm{Nc}$ & $<5$ & $<5$ & $<5$ & 93 \\
\hline Malathion & $<5$ & $\mathrm{Nc}$ & $<5$ & $\mathrm{Nc}$ & $<5$ & $<5$ & $<5$ & 78 \\
\hline Metalaxyl & $<.08$ & $\mathrm{~Np}$ & $<.08$ & $\mathrm{~Np}$ & $<.08$ & $<.08$ & $<.08$ & 103 \\
\hline Methyl azinphos & $<5$ & $\mathrm{Nc}$ & $<5$ & $\mathrm{Nc}$ & $<5$ & $<5$ & $<5$ & 73 \\
\hline Methyl parathion & $<5$ & $\mathrm{Nc}$ & $<5$ & $\mathrm{Nc}$ & $<5$ & $<5$ & $<5$ & 37 \\
\hline Metolachlor & $<5$ & $\mathrm{Nc}$ & $<5$ & $\mathrm{Nc}$ & $<5$ & $<5$ & $<5$ & 65 \\
\hline Metolachlor & 48 & $\mathrm{~Np}$ & 64 & $\mathrm{~Np}$ & $<.02$ & $<.02$ & $<.02$ & 92 \\
\hline Metribuzin & $<5$ & $\mathrm{Nc}$ & $<5$ & $\mathrm{Nc}$ & $<5$ & $<5$ & $<5$ & 67 \\
\hline Molinate & $<5$ & $\mathrm{Nc}$ & $<5$ & $\mathrm{Nc}$ & $<5$ & $<5$ & $<5$ & 76 \\
\hline Napropamide & $<5$ & $\mathrm{Nc}$ & $<5$ & $\mathrm{Nc}$ & $<5$ & $<5$ & $<5$ & 77 \\
\hline Parathion & $<5$ & $\mathrm{Nc}$ & $<5$ & $\mathrm{Nc}$ & $<5$ & $<5$ & $<5$ & 58 \\
\hline Pebulate & $<5$ & $\mathrm{Nc}$ & $<5$ & $\mathrm{Nc}$ & $<5$ & $<5$ & $<5$ & 80 \\
\hline Pendimethilan & 240 & .97 & 270 & .97 & $<5$ & $<5$ & $<5$ & 81 \\
\hline Pentachloronitrobenzene & $<25$ & $\mathrm{Nc}$ & $<25$ & $\mathrm{Nc}$ & $<25$ & $<25$ & $<25$ & 114 \\
\hline Pentachlorophenol & 330 & $\mathrm{~Np}$ & $<.16$ & $\mathrm{~Np}$ & $<.16$ & $<.16$ & $<.16$ & 104 \\
\hline Permethrin & $<5$ & $\mathrm{Nc}$ & $<5$ & $\mathrm{Nc}$ & $<5$ & $<5$ & $<5$ & 80 \\
\hline Phorate & $<5$ & $\mathrm{Nc}$ & $<5$ & $\mathrm{Nc}$ & $<5$ & $<5$ & $<5$ & 102 \\
\hline Prometon & $<5$ & $\mathrm{Nc}$ & $<5$ & $\mathrm{Nc}$ & $<5$ & $<5$ & $<5$ & 71 \\
\hline Prometon & 110 & $\mathrm{~Np}$ & $<.08$ & $\mathrm{~Np}$ & $<.08$ & $<.08$ & $<.08$ & 97 \\
\hline Mirex & $<1.5$ & $\mathrm{Nc}$ & $<1.5$ & $\mathrm{Nc}$ & $<1.5$ & $<1.5$ & $<1.5$ & 93 \\
\hline
\end{tabular}


Appendix 4. Concentrations of pesticides, pesticide metabolites, polychlorinated biphenyl compounds, polycyclic aromatic hydrocarbons, and other types of synthetic organic compounds measured in extracts from Semipermeable Membrane Devices or Polar Organic Chemical Integrative Samplers submerged at two stream sites on the North Canadian River adjacent to the Kickapoo tribal lands in central Oklahoma, January-February 2009.-Continued

[Compound concentrations measured in extracts are reported in nanogram per ampoule of extract from a composite of three SPMD or three POCIS media in each sampler. Compounds that are bolded were considered detected because concentration was three times, or greater, than the highest concentration measured in the field or laboratory blank. A compound measured by more than one laboratory method was counted only once as a detection; site identifier, stream-gaging station and (number); N., north; ng/L, nanogram of compound per liter of water; ng/ampoule, nanogram of compound per ampoule of extract; <, less than; E, concentration is approximate because trace levels of contamination were found in the blanks at levels below the reporting level; R-Delete, spike fraction was lost during sample preparation at laboratory; --, not applicable; *, indicates compound could not be positively identified in the extract below the reported concentration because of chromatographic interference; Nc, not calculated because presence of the compound could not be positively identified in the extract or concentration was below the laboratory reporting level; UD, compound was not recovered most likely because of residual isopropanol from the addition of spike and surrogate solution; Np, water concentration could not be calculated because compound was measured in extract from Polar Organic Integrative Sampler which did not have performance reference compounds needed for calculation]

\begin{tabular}{|c|c|c|c|c|c|c|c|c|}
\hline \multirow[t]{2}{*}{ Compound } & \multicolumn{2}{|c|}{$\begin{array}{c}\text { PS-1 } \\
\text { N. Canadian River at } \\
\text { Hogback Road near } \\
\text { Jones, Oklahoma } \\
\text { (07241540) } \\
\end{array}$} & \multicolumn{2}{|c|}{$\begin{array}{c}\text { PS-2 } \\
\text { N. Canadian River } \\
\text { near Shawnee, } \\
\text { Oklahoma } \\
(07241700) \\
\end{array}$} & \multirow[t]{2}{*}{$\begin{array}{c}\text { Field blank } \\
\text { (ng/ampoule) }\end{array}$} & \multirow[t]{2}{*}{$\begin{array}{l}\text { Laboratory } \\
\text { blank } \\
\text { (ng/ampoule) }\end{array}$} & \multirow[t]{2}{*}{$\begin{array}{l}\text { Laboratory } \\
\text { reporting } \\
\text { level } \\
\text { (ng/ampoule) }\end{array}$} & \multirow[t]{2}{*}{$\begin{array}{l}\text { Laboratory } \\
\text { spike } \\
\text { (percent } \\
\text { recovery) }\end{array}$} \\
\hline & (ng/ampoule) & (ng/L) & (ng/ampoule) & (ng/L) & & & & \\
\hline$\overline{p, p^{\prime}-\mathrm{DDT}}$ & $<1.0$ & $\mathrm{Nc}$ & $<1.0$ & $\mathrm{Nc}$ & $<1.0$ & $<1.0$ & $<1.0$ & R-Delete \\
\hline$p, p^{\prime}$-Methoxychlor & $<3.5$ & $\mathrm{Nc}$ & $<3.5$ & $\mathrm{Nc}$ & $<3.5$ & $<3.5$ & $<3.5$ & R-Delete \\
\hline Toxaphene & $<200$ & $\mathrm{Nc}$ & $<200$ & $\mathrm{Nc}$ & $<200$ & $<200$ & $<200$ & $<200$ \\
\hline Propachlor & $<5$ & $\mathrm{Nc}$ & $<5$ & $\mathrm{Nc}$ & $<5$ & $<5$ & $<5$ & 76 \\
\hline Propanil & $<5$ & $\mathrm{Nc}$ & $<5$ & $\mathrm{Nc}$ & $<5$ & $<5$ & $<5$ & 71 \\
\hline Propargite & $<5$ & $\mathrm{Nc}$ & $<5$ & $\mathrm{Nc}$ & $<5$ & $<5$ & $<5$ & 66 \\
\hline Propyzamide & $<5$ & $\mathrm{Nc}$ & $<5$ & $\mathrm{Nc}$ & $<5$ & $<5$ & $<5$ & 66 \\
\hline Simazine & $<5$ & $\mathrm{Nc}$ & $<5$ & $\mathrm{Nc}$ & $<5$ & $<5$ & $<5$ & 76 \\
\hline Tebuthiuron & $<5$ & $\mathrm{Nc}$ & $<5$ & $\mathrm{Nc}$ & $<5$ & $<5$ & $<5$ & 61 \\
\hline Terbacil & $<5$ & $\mathrm{Nc}$ & $<5$ & $\mathrm{Nc}$ & $<5$ & $<5$ & $<5$ & 74 \\
\hline Terbufos & $<5$ & $\mathrm{Nc}$ & $<5$ & $\mathrm{Nc}$ & $<5$ & $<5$ & $<5$ & 82 \\
\hline Thiobencarb & $<5$ & $\mathrm{Nc}$ & $<5$ & $\mathrm{Nc}$ & $<5$ & $<5$ & $<5$ & 75 \\
\hline trans-Nonachlor & E32 & E.15 & E18 & E.07 & $<1.0$ & $<1.0$ & $<1.0$ & R-Delete \\
\hline Triallate & $<5$ & $\mathrm{Nc}$ & $<5$ & $\mathrm{Nc}$ & $<5$ & $<5$ & $<5$ & 86 \\
\hline Trifluralin & $<5$ & $\mathrm{Nc}$ & $<5$ & $\mathrm{Nc}$ & $<5$ & $<5$ & $<5$ & 65 \\
\hline Number of detections & \multicolumn{2}{|l|}{10} & \multicolumn{2}{|l|}{7} & -- & -- & -- & -- \\
\hline \multicolumn{9}{|c|}{ Pesticide metabolites } \\
\hline cis-Chlordane & E100 & E.47 & E66 & E.26 & $<1.0$ & $<1.0$ & $<1.0$ & R-Delete \\
\hline trans-Chlordane & E98.0 & E.44 & E42.0 & E.16 & $<.5$ & $<.5$ & $<.5$ & R-Delete \\
\hline$p, p^{\prime}-\mathrm{DDD}$ & $<2.5$ & $\mathrm{Nc}$ & $<2.5$ & $\mathrm{Nc}$ & $<2.5$ & $<2.5$ & $<2.5$ & R-Delete \\
\hline$p, p^{\prime}-\mathrm{DDE}$ & E14 & E.02 & $<1.5$ & $\mathrm{Nc}$ & $<1.5$ & $<1.5$ & $<1.5$ & 100 \\
\hline$p, p^{\prime}-\mathrm{DDE}$ & 22.9 & .09 & 16.9 & .06 & $<5$ & $<5$ & $<5$ & 63 \\
\hline Deethylatrazine & $<5$ & $\mathrm{Nc}$ & $<5$ & $\mathrm{Nc}$ & $<5$ & $<5$ & $<5$ & 80 \\
\hline Desulfinylfipronil & $<5$ & $\mathrm{Nc}$ & $<5$ & $\mathrm{Nc}$ & $<5$ & $<5$ & $<5$ & 59 \\
\hline Desulfinylfipronil amide & $<5$ & $\mathrm{Nc}$ & $<5$ & $\mathrm{Nc}$ & $<5$ & $<5$ & $<5$ & 61 \\
\hline Fipronil sulfide & $<5$ & $\mathrm{Nc}$ & $<5$ & $\mathrm{Nc}$ & $<5$ & $<5$ & $<5$ & 42 \\
\hline Fipronil sulfone & $<5$ & $\mathrm{Nc}$ & $<5$ & $\mathrm{Nc}$ & $<5$ & $<5$ & $<5$ & 33 \\
\hline Heptachlor epoxide & 5.5 & .03 & 35.5 & .15 & $<1.5$ & $<1.5$ & $<1.5$ & R-Delete \\
\hline Number of detections & 4 & & 4 & & -- & -- & -- & -- \\
\hline
\end{tabular}


Appendix 4. Concentrations of pesticides, pesticide metabolites, polychlorinated biphenyl compounds, polycyclic aromatic hydrocarbons, and other types of synthetic organic compounds measured in extracts from Semipermeable Membrane Devices or Polar Organic Chemical Integrative Samplers submerged at two stream sites on the North Canadian River adjacent to the Kickapoo tribal lands in central Oklahoma, January-February 2009.-Continued

[Compound concentrations measured in extracts are reported in nanogram per ampoule of extract from a composite of three SPMD or three POCIS media in each sampler. Compounds that are bolded were considered detected because concentration was three times, or greater, than the highest concentration measured in the field or laboratory blank. A compound measured by more than one laboratory method was counted only once as a detection; site identifier, stream-gaging station and (number); N., north; ng/L, nanogram of compound per liter of water; ng/ampoule, nanogram of compound per ampoule of extract; <, less than; E, concentration is approximate because trace levels of contamination were found in the blanks at levels below the reporting level; R-Delete, spike fraction was lost during sample preparation at laboratory; --, not applicable; *, indicates compound could not be positively identified in the extract below the reported concentration because of chromatographic interference; Nc, not calculated because presence of the compound could not be positively identified in the extract or concentration was below the laboratory reporting level; UD, compound was not recovered most likely because of residual isopropanol from the addition of spike and surrogate solution; $\mathrm{Np}$, water concentration could not be calculated because compound was measured in extract from Polar Organic Integrative Sampler which did not have performance reference compounds needed for calculation]

\begin{tabular}{|c|c|c|c|c|c|c|c|c|}
\hline \multirow[t]{2}{*}{ Compound } & \multicolumn{2}{|c|}{$\begin{array}{c}\text { PS-1 } \\
\text { N. Canadian River at } \\
\text { Hogback Road near } \\
\text { Jones, Oklahoma } \\
\text { (07241540) }\end{array}$} & \multicolumn{2}{|c|}{$\begin{array}{c}\text { PS-2 } \\
\text { N. Canadian River } \\
\text { near Shawnee, } \\
\text { Oklahoma } \\
(07241700)\end{array}$} & \multirow[t]{2}{*}{$\begin{array}{c}\text { Field blank } \\
\text { (ng/ampoule) }\end{array}$} & \multirow[t]{2}{*}{$\begin{array}{c}\text { Laboratory } \\
\text { blank } \\
\text { (ng/ampoule) }\end{array}$} & \multirow[t]{2}{*}{$\begin{array}{l}\text { Laboratory } \\
\text { reporting } \\
\text { level } \\
\text { (ng/ampoule) }\end{array}$} & \multirow[t]{2}{*}{$\begin{array}{l}\text { Laboratory } \\
\text { spike } \\
\text { (percent } \\
\text { recovery) }\end{array}$} \\
\hline & (ng/ampoule) & (ng/L) & (ng/ampoule) & (ng/L) & & & & \\
\hline \multicolumn{9}{|c|}{ Polychlorinated biphenyls } \\
\hline Aroclor 1254 & 130 & 2.3 & 120 & .69 & $<.5$ & $<5.0$ & $<5.0$ & 96 \\
\hline Aroclor 1260 & 170 & 3.0 & 150 & 2.20 & $<.5$ & $<5.0$ & $<5.0$ & 99 \\
\hline Number of detections & 3 & & 3 & & -- & -- & -- & -- \\
\hline \multicolumn{9}{|c|}{ Polyaromatic hydrocarbons } \\
\hline 1,6-Dimethylnaphthalene & E180 & E1.06 & E110 & E.62 & E110 & $<25$ & $<25$ & 105 \\
\hline 1-Methyl-9H-fluorene & $<180^{*}$ & $\mathrm{Nc}$ & $<150^{*}$ & $\mathrm{Nc}$ & $<120^{*}$ & $<25$ & $<25$ & 106 \\
\hline 1-Methylphenanthrene & E200 & E.75 & E79 & E.26 & $<25$ & $<25$ & $<25$ & 118 \\
\hline 1-Methylpyrene & E230 & E.83 & E130 & E.41 & $<25$ & $<25$ & $<25$ & 118 \\
\hline 2,3,6-Trimethylnaphthalene & E188 & E.76 & $\mathrm{E} 150$ & E.53 & E130 & $<25$ & $<25$ & 111 \\
\hline 2,6-Dimethylnaphthalene & E210 & $\mathrm{E} 1.13$ & E150 & E.74 & E150 & $<25$ & $<25$ & 118 \\
\hline 2,6-Dimethylnaphthalene & $<18.4^{*}$ & $\mathrm{~Np}$ & $<.02$ & $\mathrm{~Np}$ & 5.2 & $<.02$ & $<.02$ & 99 \\
\hline 2-Ethylnaphthalene & E130 & E. 81 & E110 & E.62 & $\mathrm{E} 110$ & $<25$ & $<25$ & 116 \\
\hline Acenaphthylene & E150 & E1.11 & $<140 *$ & $\mathrm{Nc}$ & $<140^{*}$ & $<25$ & $<25$ & 105 \\
\hline Anthracene & $<160 *$ & $\mathrm{Nc}$ & $<120^{*}$ & $\mathrm{Nc}$ & $<25$ & $<25$ & $<25$ & 121 \\
\hline Anthracene & $<28.4^{*}$ & $\mathrm{~Np}$ & $<34^{*}$ & $\mathrm{~Np}$ & $<.01$ & $<.01$ & $<.01$ & 96 \\
\hline Anthraquinone & $<890^{*}$ & $\mathrm{Nc}$ & $<440^{*}$ & $\mathrm{Nc}$ & $<25$ & $<25$ & $<25$ & 111 \\
\hline Anthraquinone & $<56^{*}$ & $\mathrm{~Np}$ & $<.02$ & $\mathrm{~Np}$ & $<.02$ & $<.02$ & $<.02$ & 92 \\
\hline $\operatorname{Benz}(a)$ anthracene & E310 & E1.24 & $<1,700^{*}$ & $\mathrm{Nc}$ & $<25$ & $<25$ & $<25$ & 115 \\
\hline
\end{tabular}


Appendix 4. Concentrations of pesticides, pesticide metabolites, polychlorinated biphenyl compounds, polycyclic aromatic hydrocarbons, and other types of synthetic organic compounds measured in extracts from Semipermeable Membrane Devices or Polar Organic Chemical Integrative Samplers submerged at two stream sites on the North Canadian River adjacent to the Kickapoo tribal lands in central Oklahoma, January-February 2009.-Continued

[Compound concentrations measured in extracts are reported in nanogram per ampoule of extract from a composite of three SPMD or three POCIS media in each sampler. Compounds that are bolded were considered detected because concentration was three times, or greater, than the highest concentration measured in the field or laboratory blank. A compound measured by more than one laboratory method was counted only once as a detection; site identifier, stream-gaging station and (number); N., north; ng/L, nanogram of compound per liter of water; ng/ampoule, nanogram of compound per ampoule of extract; <, less than; E, concentration is approximate because trace levels of contamination were found in the blanks at levels below the reporting level; R-Delete, spike fraction was lost during sample preparation at laboratory; --, not applicable; *, indicates compound could not be positively identified in the extract below the reported concentration because of chromatographic interference; Nc, not calculated because presence of the compound could not be positively identified in the extract or concentration was below the laboratory reporting level; UD, compound was not recovered most likely because of residual isopropanol from the addition of spike and surrogate solution; Np, water concentration could not be calculated because compound was measured in extract from Polar Organic Integrative Sampler which did not have performance reference compounds needed for calculation]

\begin{tabular}{|c|c|c|c|c|c|c|c|c|}
\hline \multirow[t]{2}{*}{ Compound } & \multicolumn{2}{|c|}{$\begin{array}{c}\text { PS-1 } \\
\text { N. Canadian River at } \\
\text { Hogback Road near } \\
\text { Jones, Oklahoma } \\
\text { (07241540) }\end{array}$} & \multicolumn{2}{|c|}{$\begin{array}{c}\text { PS-2 } \\
\text { N. Canadian River } \\
\text { near Shawnee, } \\
\text { Oklahoma } \\
(07241700)\end{array}$} & \multirow[t]{2}{*}{$\begin{array}{l}\text { Field blank } \\
\text { (ng/ampoule) }\end{array}$} & \multirow[t]{2}{*}{$\begin{array}{c}\text { Laboratory } \\
\text { blank } \\
\text { (ng/ampoule) }\end{array}$} & \multirow[t]{2}{*}{$\begin{array}{l}\text { Laboratory } \\
\text { reporting } \\
\text { level } \\
\text { (ng/ampoule) }\end{array}$} & \multirow[t]{2}{*}{$\begin{array}{l}\text { Laboratory } \\
\text { spike } \\
\text { (percent } \\
\text { recovery) }\end{array}$} \\
\hline & (ng/ampoule) & (ng/L) & (ng/ampoule) & (ng/L) & & & & \\
\hline Benzo(a)pyrene & $<170 *$ & $\mathrm{Nc}$ & $<250^{*}$ & $\mathrm{Nc}$ & $<25$ & $<25$ & $<25$ & 112 \\
\hline Benzo(b)fluoranthene & E320 & E1.23 & $<900^{*}$ & $\mathrm{Nc}$ & $<25$ & $<25$ & $<25$ & 118 \\
\hline Benzo(e)pyrene & E270 & E1.31 & $<1,100^{*}$ & $\mathrm{Nc}$ & $<25$ & $<25$ & $<25$ & 102 \\
\hline Benzo(ghi)perylene & E210 & E1.33 & $<250^{*}$ & $\mathrm{Nc}$ & $<25$ & $<25$ & $<25$ & 102 \\
\hline $\operatorname{Benzo}(k)$ fluoranthene & E190 & E.82 & $<250^{*}$ & $\mathrm{Nc}$ & $<25$ & $<25$ & $<25$ & 119 \\
\hline Dibenzothiophene & E170 & E.90 & $<110^{*}$ & $\mathrm{Nc}$ & $<70$ & $<25$ & $<25$ & 116 \\
\hline Fluoranthene & 3,440 & 12.6 & 1,900 & 6.12 & E84 & $<25$ & $<25$ & 127 \\
\hline Fluoranthene & $<8^{*}$ & $\mathrm{~Np}$ & $<.01$ & $\mathrm{~Np}$ & $<8^{*}$ & .64 & $<.01$ & 96 \\
\hline Indeno(1,2,3-cd)pyrene & $<220 *$ & $\mathrm{Nc}$ & $<250 *$ & $\mathrm{Nc}$ & $<25$ & $<25$ & $<25$ & 107 \\
\hline Naphthalene & E190 & $\mathrm{E} 4.70$ & E140 & E3.43 & E230 & $<25$ & $<25$ & 109 \\
\hline Naphthalene & 14 & $\mathrm{~Np}$ & $<.01$ & $\mathrm{~Np}$ & 21.2 & $<.01$ & $<.01$ & 97 \\
\hline Perylene & $<25$ & $\mathrm{Nc}$ & $<250 *$ & $\mathrm{Nc}$ & $<25$ & $<25$ & $<25$ & 112 \\
\hline Phenanthrene & 1,530 & 7.71 & E610 & E2.78 & E110 & $<25$ & $<25$ & 116 \\
\hline 3-beta-Coprostanol ${ }^{2}$ & 440 & $\mathrm{~Np}$ & $<.16$ & $\mathrm{~Np}$ & $<400 *$ & $<.16$ & $<.16$ & 61 \\
\hline 3-Methyl-1H-indole ${ }^{2}$ (skatol) & 21.2 & $\mathrm{~Np}$ & 21.2 & $\mathrm{~Np}$ & $<.02$ & $<.02$ & $<.02$ & 102 \\
\hline $\begin{array}{l}\text { 3-tert-Butyl-4-hydroxyanisole } \\
\text { (BHA) }\end{array}$ & $<.08$ & $\mathrm{~Np}$ & $<.08$ & $\mathrm{~Np}$ & $<.08$ & $<.08$ & $<.08$ & 91 \\
\hline 4-Cumylphenol & $<40^{*}$ & $\mathrm{~Np}$ & UD & $\mathrm{Np}$ & UD & UD & $<.02$ & UD \\
\hline 4-n-Octylphenol & $<64 *$ & $\mathrm{~Np}$ & UD & $\mathrm{Np}$ & UD & UD & $<.01$ & UD \\
\hline
\end{tabular}


Appendix 4. Concentrations of pesticides, pesticide metabolites, polychlorinated biphenyl compounds, polycyclic aromatic hydrocarbons, and other types of synthetic organic compounds measured in extracts from Semipermeable Membrane Devices or Polar Organic Chemical Integrative Samplers submerged at two stream sites on the North Canadian River adjacent to the Kickapoo tribal lands in central Oklahoma, January-February 2009.-Continued

[Compound concentrations measured in extracts are reported in nanogram per ampoule of extract from a composite of three SPMD or three POCIS media in each sampler. Compounds that are bolded were considered detected because concentration was three times, or greater, than the highest concentration measured in the field or laboratory blank. A compound measured by more than one laboratory method was counted only once as a detection; site identifier, stream-gaging station and (number); N., north; ng/L, nanogram of compound per liter of water; ng/ampoule, nanogram of compound per ampoule of extract; <, less than; E, concentration is approximate because trace levels of contamination were found in the blanks at levels below the reporting level; R-Delete, spike fraction was lost during sample preparation at laboratory; --, not applicable; *, indicates compound could not be positively identified in the extract below the reported concentration because of chromatographic interference; $\mathrm{Nc}$, not calculated because presence of the compound could not be positively identified in the extract or concentration was below the laboratory reporting level; UD, compound was not recovered most likely because of residual isopropanol from the addition of spike and surrogate solution; $\mathrm{Np}$, water concentration could not be calculated because compound was measured in extract from Polar Organic Integrative Sampler which did not have performance reference compounds needed for calculation]

\begin{tabular}{|c|c|c|c|c|c|c|c|c|}
\hline \multirow[t]{2}{*}{ Compound } & \multicolumn{2}{|c|}{$\begin{array}{c}\text { PS-1 } \\
\text { N. Canadian River at } \\
\text { Hogback Road near } \\
\text { Jones, Oklahoma } \\
\text { (07241540) }\end{array}$} & \multicolumn{2}{|c|}{$\begin{array}{c}\text { PS-2 } \\
\text { N. Canadian River } \\
\text { near Shawnee, } \\
\text { Oklahoma } \\
(07241700) \\
\end{array}$} & \multirow[t]{2}{*}{$\begin{array}{l}\text { Field blank } \\
\text { (ng/ampoule) }\end{array}$} & \multirow[t]{2}{*}{$\begin{array}{l}\text { Laboratory } \\
\text { blank } \\
\text { (ng/ampoule) }\end{array}$} & \multirow[t]{2}{*}{$\begin{array}{l}\text { Laboratory } \\
\text { reporting } \\
\text { level } \\
\text { (ng/ampoule) }\end{array}$} & \multirow[t]{2}{*}{$\begin{array}{c}\text { Laboratory } \\
\text { spike } \\
\text { (percent } \\
\text { recovery) }\end{array}$} \\
\hline & (ng/ampoule) & (ng/L) & (ng/ampoule) & (ng/L) & & & & \\
\hline $\begin{array}{l}\text { 4-Nonylphenol diethoxylate } \\
\text { (NP2EO; total) }\end{array}$ & $<4,000^{*}$ & $\mathrm{~Np}$ & UD & $\mathrm{Np}$ & 720 & UD & $<0.32$ & UD \\
\hline $\begin{array}{l}\text { 4-Nonylphenol monoethoxylate } \\
\text { (NP1EO; total) }\end{array}$ & $<1,520^{*}$ & $\mathrm{~Np}$ & UD & $\mathrm{Np}$ & UD & UD & $<.06$ & UD \\
\hline $\begin{array}{l}\text { 4-tert-Octylphenol diethoxyl- } \\
\text { ate }^{1,7} \text { (OP2EO; total) }\end{array}$ & 1,440 & $\mathrm{~Np}$ & UD & $\mathrm{Np}$ & $<640^{*}$ & UD & $<.02$ & UD \\
\hline $\begin{array}{l}\text { 4-tert-Octylphenol monoethox- } \\
\text { ylate (OP1EO; total) }\end{array}$ & $<1,160^{*}$ & $\mathrm{~Np}$ & $<.06$ & $\mathrm{~Np}$ & $<120^{*}$ & $<.06$ & $<.06$ & 76 \\
\hline 4-tert-Octylphenol & E44 & $\mathrm{Np}$ & $<.01$ & $\mathrm{~Np}$ & E2.8 & $<.01$ & $<.01$ & 89 \\
\hline 5-methyl-1H-benzotriazole ${ }^{4}$ & 2,200 & $\mathrm{~Np}$ & 1,320 & $\mathrm{~Np}$ & $<.16$ & $<.16$ & $<.16$ & 101 \\
\hline Acetophenone $^{5}$ & 160 & $\mathrm{~Np}$ & 180 & $\mathrm{~Np}$ & 40 & $<.04$ & $<.04$ & 93 \\
\hline Benzophenone $e^{5,7}$ & 210 & $\mathrm{~Np}$ & 180 & $\mathrm{~Np}$ & 44 & $<.04$ & $<.04$ & 100 \\
\hline beta-Sitosterol ${ }^{6}$ & 1,360 & $\mathrm{~Np}$ & UD & $\mathrm{Np}$ & UD & UD & $<.39$ & UD \\
\hline beta-Stigmastanol & $<6,400^{*}$ & $\mathrm{~Np}$ & $<.10$ & $\mathrm{~Np}$ & $<3,960^{*}$ & $<.10$ & $<.10$ & 143 \\
\hline Bisphenol A & $<840^{*}$ & $\mathrm{~Np}$ & $<400^{*}$ & $\mathrm{~Np}$ & 26.4 & UD & $<.02$ & UD \\
\hline Bromoform & $<.08$ & $\mathrm{~Np}$ & $<.08$ & $\mathrm{~Np}$ & $<.08$ & $<.08$ & $<.08$ & 92 \\
\hline Caffeine & $<150^{*}$ & $\mathrm{~Np}$ & $<.04$ & $\mathrm{~Np}$ & $<10.4^{*}$ & $<.04$ & $<.04$ & 98 \\
\hline Camphor & $<.04$ & $\mathrm{~Np}$ & $<.04$ & $\mathrm{~Np}$ & 4.4 & $<.04$ & $<.04$ & 96 \\
\hline Cholesterol & $\mathrm{E} 3,640$ & $\mathrm{~Np}$ & $<.16$ & $\mathrm{~Np}$ & $\mathrm{E} 3,040$ & $<.16$ & $<.16$ & 51 \\
\hline Cotinine & $<100^{*}$ & $\mathrm{~Np}$ & $<.04$ & $\mathrm{~Np}$ & 27.2 & $<.04$ & $<.04$ & 93 \\
\hline Cumene (Isopropylbenzene) & .02 & $\mathrm{~Np}$ & .02 & $\mathrm{~Np}$ & 2.24 & .02 & .02 & 95 \\
\hline Bis(2-ethylhexyl)phthalate & $\mathrm{E} 450$ & E8.63 & $<800^{*}$ & $\mathrm{Nc}$ & $\mathrm{E} 430$ & $<90^{*}$ & $<90^{*}$ & 112 \\
\hline d-Limonene & 19.2 & $\mathrm{~Np}$ & $<.08$ & $\mathrm{~Np}$ & 10.4 & $<.08$ & $<.08$ & 91 \\
\hline Diethylphthalate & E273 & E72.5 & E250 & E65.3 & E260 & $<45^{*}$ & $<45^{*}$ & 105 \\
\hline Ethyl citrate & $<.02$ & $<.02$ & $<.02$ & $<.02$ & $<.02$ & $<.02$ & $<.02$ & 85 \\
\hline Galaxolide $^{5,7}$ (HHCB) & 3,200 & $\mathrm{~Np}$ & 1,240 & $\mathrm{~Np}$ & 26.4 & $<.02$ & $<.02$ & 94 \\
\hline Indole $^{4}$ & 200 & $\mathrm{~Np}$ & 320 & $\mathrm{~Np}$ & $<.02$ & $<.02$ & $<.02$ & 101 \\
\hline Isoborneol & $<29.6^{*}$ & $\mathrm{~Np}$ & UD & $\mathrm{Np}$ & UD & UD & $<.04$ & UD \\
\hline Isophorone $^{4}$ & 92 & $\mathrm{~Np}$ & 160 & $\mathrm{~Np}$ & 2.64 & $<.02$ & $<.02$ & 87 \\
\hline Isoquinoline & $<18.4^{*}$ & $\mathrm{~Np}$ & $<.02$ & $\mathrm{~Np}$ & $<4.4^{*}$ & $<.02$ & $<.02$ & 92 \\
\hline Menthol & $<64^{*}$ & $\mathrm{~Np}$ & UD & $\mathrm{Np}$ & UD & UD & $<.16$ & UD \\
\hline
\end{tabular}


Appendix 4. Concentrations of pesticides, pesticide metabolites, polychlorinated biphenyl compounds, polycyclic aromatic hydrocarbons, and other types of synthetic organic compounds measured in extracts from Semipermeable Membrane Devices or Polar Organic Chemical Integrative Samplers submerged at two stream sites on the North Canadian River adjacent to the Kickapoo tribal lands in central Oklahoma, January-February 2009. - Continued

[Compound concentrations measured in extracts are reported in nanogram per ampoule of extract from a composite of three SPMD or three POCIS media in each sampler. Compounds that are bolded were considered detected because concentration was three times, or greater, than the highest concentration measured in the field or laboratory blank. A compound measured by more than one laboratory method was counted only once as a detection; site identifier, stream-gaging station and (number); N., north; ng/L, nanogram of compound per liter of water; ng/ampoule, nanogram of compound per ampoule of extract; <, less than; E, concentration is approximate because trace levels of contamination were found in the blanks at levels below the reporting level; R-Delete, spike fraction was lost during sample preparation at laboratory; --, not applicable; *, indicates compound could not be positively identified in the extract below the reported concentration because of chromatographic interference; Nc, not calculated because presence of the compound could not be positively identified in the extract or concentration was below the laboratory reporting level; UD, compound was not recovered most likely because of residual isopropanol from the addition of spike and surrogate solution; Np, water concentration could not be calculated because compound was measured in extract from Polar Organic Integrative Sampler which did not have performance reference compounds needed for calculation]

\begin{tabular}{|c|c|c|c|c|c|c|c|c|}
\hline \multirow[t]{2}{*}{ Compound } & \multicolumn{2}{|c|}{$\begin{array}{c}\text { PS-1 } \\
\text { N. Canadian River at } \\
\text { Hogback Road near } \\
\text { Jones, Oklahoma } \\
\text { (07241540) }\end{array}$} & \multicolumn{2}{|c|}{$\begin{array}{c}\text { PS-2 } \\
\text { N. Canadian River } \\
\text { near Shawnee, } \\
\text { Oklahoma } \\
(07241700)\end{array}$} & \multirow[t]{2}{*}{$\begin{array}{l}\text { Field blank } \\
\text { (ng/ampoule) }\end{array}$} & \multirow[t]{2}{*}{$\begin{array}{c}\text { Laboratory } \\
\text { blank } \\
\text { (ng/ampoule) }\end{array}$} & \multirow[t]{2}{*}{$\begin{array}{l}\text { Laboratory } \\
\text { reporting } \\
\text { level } \\
\text { (ng/ampoule) }\end{array}$} & \multirow[t]{2}{*}{$\begin{array}{l}\text { Laboratory } \\
\text { spike } \\
\text { (percent } \\
\text { recovery) }\end{array}$} \\
\hline & (ng/ampoule) & (ng/L) & (ng/ampoule) & (ng/L) & & & & \\
\hline Methyl salicylate & 76 & $\mathrm{~Np}$ & $<0.04$ & $\mathrm{~Np}$ & 38.8 & $<0.04$ & $<0.04$ & 96 \\
\hline p-Cresol ${ }^{4}$ & 252 & $\mathrm{~Np}$ & $<108^{*}$ & $\mathrm{~Np}$ & 38 & $<.04$ & $<.04$ & 80 \\
\hline Pentachloroanisol $^{4,7}$ & E270 & E.98 & E88 & E.28 & $<25$ & $<25$ & $<25$ & 110 \\
\hline Phenanthridine & $<25$ & $\mathrm{Nc}$ & $<25$ & $\mathrm{Nc}$ & $<25$ & $<25$ & $<25$ & 115 \\
\hline p-Nonylphenol ${ }^{1,7}$ (total) & 1,600 & $\mathrm{~Np}$ & $<1,120^{*}$ & $\mathrm{~Np}$ & 384 & $<.16$ & $<.16$ & 88 \\
\hline Tonalide (AHTN) $)^{5,7}$ & 376 & $\mathrm{~Np}$ & 116 & $\mathrm{~Np}$ & 5.6 & $<.02$ & $<.02$ & 102 \\
\hline Tri(2-butoxyethyl) phosphate ${ }^{3}$ & $\mathbf{E 3}, 480$ & $\mathrm{~Np}$ & E2,040 & $\mathrm{Np}$ & $<.08$ & $<.08$ & $<.08$ & 91 \\
\hline Tri(2-chloroethyl) phosphate ${ }^{3,7}$ & 560 & $\mathrm{~Np}$ & 480 & $\mathrm{~Np}$ & $<.08$ & $<.08$ & $<.08$ & 97 \\
\hline Tributyl phosphate ${ }^{4}$ & E560 & $\mathrm{Np}$ & E290 & $\mathrm{Np}$ & E13.6 & $<.02$ & $<.02$ & 82 \\
\hline Triclosan $^{1}$ & E760 & $\mathrm{Np}$ & $<.02$ & $\mathrm{~Np}$ & $<.02$ & $<.02$ & $<.02$ & 88 \\
\hline $\begin{array}{l}\text { Tri(dichlorisopropyl) phos- } \\
\text { phate }^{3,7}\end{array}$ & 480 & $\mathrm{~Np}$ & 480 & $\mathrm{~Np}$ & $<.16$ & $<.16$ & $<.16$ & 89 \\
\hline Triethyl citrate & $<.02$ & $\mathrm{~Np}$ & $<.02$ & $\mathrm{~Np}$ & $<.02$ & $<.02$ & $<.02$ & 85 \\
\hline Triphenyl phosphate & $<.04$ & $\mathrm{~Np}$ & $<.04$ & $\mathrm{~Np}$ & $<.04$ & $<.04$ & $<.04$ & 98 \\
\hline Nonachlor & 92 & & 89 & & 88 & 90 & -- & 84 \\
\hline alpha-Hexachlorocyclohexane & 74 & & 66 & & 79 & 89 & -- & R-Delete \\
\hline Nitrobenzene-d5 & 89 & & 92 & & 90 & 95 & -- & 133 \\
\hline 2-Fluorobiphenyl & 92 & & 97 & & 83 & 95 & -- & 110 \\
\hline Terphenyl-d14 & 96 & & 97 & & 102 & 95 & -- & 96 \\
\hline Decafluorobiphenyl & 93 & & 96 & & 84 & 95 & -- & 92 \\
\hline d8-Caffeine & 107 & & 92 & & 96 & 82 & -- & 91 \\
\hline
\end{tabular}


Appendix 4. Concentrations of pesticides, pesticide metabolites, polychlorinated biphenyl compounds, polycyclic aromatic hydrocarbons, and other types of synthetic organic compounds measured in extracts from Semipermeable Membrane Devices or Polar Organic Chemical Integrative Samplers submerged at two stream sites on the North Canadian River adjacent to the Kickapoo tribal lands in central Oklahoma, January-February 2009._-Continued

[Compound concentrations measured in extracts are reported in nanogram per ampoule of extract from a composite of three SPMD or three POCIS media in each sampler. Compounds that are bolded were considered detected because concentration was three times, or greater, than the highest concentration measured in the field or laboratory blank. A compound measured by more than one laboratory method was counted only once as a detection; site identifier, stream-gaging station and (number); N., north; ng/L, nanogram of compound per liter of water; ng/ampoule, nanogram of compound per ampoule of extract; <, less than; E, concentration is approximate because trace levels of contamination were found in the blanks at levels below the reporting level; R-Delete, spike fraction was lost during sample preparation at laboratory; --, not applicable; *, indicates compound could not be positively identified in the extract below the reported concentration because of chromatographic interference; $\mathrm{Nc}$, not calculated because presence of the compound could not be positively identified in the extract or concentration was below the laboratory reporting level; UD, compound was not recovered most likely because of residual isopropanol from the addition of spike and surrogate solution; Np, water concentration could not be calculated because compound was measured in extract from Polar Organic Integrative Sampler which did not have performance reference compounds needed for calculation]

\begin{tabular}{|c|c|c|c|c|c|c|c|c|}
\hline \multirow[t]{2}{*}{ Compound } & \multicolumn{2}{|c|}{$\begin{array}{c}\text { PS-1 } \\
\text { N. Canadian River at } \\
\text { Hogback Road near } \\
\text { Jones, Oklahoma } \\
\text { (07241540) }\end{array}$} & \multicolumn{2}{|c|}{$\begin{array}{c}\text { PS-2 } \\
\text { N. Canadian River } \\
\text { near Shawnee, } \\
\text { Oklahoma } \\
\text { (07241700) }\end{array}$} & \multirow[t]{2}{*}{$\begin{array}{c}\text { Field blank } \\
\text { (ng/ampoule) }\end{array}$} & \multirow[t]{2}{*}{$\begin{array}{c}\text { Laboratory } \\
\text { blank } \\
\text { (ng/ampoule) }\end{array}$} & \multirow[t]{2}{*}{$\begin{array}{l}\text { Laboratory } \\
\text { reporting } \\
\text { level } \\
\text { (ng/ampoule) }\end{array}$} & \multirow[t]{2}{*}{$\begin{array}{c}\text { Laboratory } \\
\text { spike } \\
\text { (percent } \\
\text { recovery) }\end{array}$} \\
\hline & (ng/ampoule) & (ng/L) & (ng/ampoule) & (ng/L) & & & & \\
\hline d10-Fluoranthene & 97 & & 94 & & 94 & 90 & -- & 88 \\
\hline
\end{tabular}

\footnotetext{
${ }^{1}$ Detergent.

${ }^{2}$ Fecal indicator.

${ }^{3}$ Flame retardant.

${ }^{4}$ Industrial compound.

${ }^{5}$ Personal care product.

${ }^{6}$ Plant sterol.

${ }^{7}$ Suspected or known endocrine disruptor.
} 
